Prepared in cooperation with the Coalition of Six Middle Rio Grande Basin Pueblos

\title{
Survey of Hydrologic Models and Hydrologic Data Needs for Tracking Flow in the Rio Grande, North-Central New Mexico, 2010
}

Scientific Investigations Report 2011-5207 



\section{Survey of Hydrologic Models and Hydrologic Data Needs for Tracking Flow in the Rio Grande, North-Central New Mexico, 2010}

By Anne Tillery and Jack R. Eggleston

Prepared in cooperation with the Coalition of Six Middle Rio Grande Basin

Pueblos

Scientific Investigations Report 2011-5207 


\title{
U.S. Department of the Interior \\ KEN SALAZAR, Secretary \\ U.S. Geological Survey \\ Marcia K. McNutt, Director
}

\section{U.S. Geological Survey, Reston, Virginia: 2012}

\author{
This and other USGS information products are available at http://store.usgs.gov/ \\ U.S. Geological Survey \\ Box 25286, Denver Federal Center \\ Denver, CO 80225 \\ To learn about the USGS and its information products visit http://www.usgs.gov/ \\ 1-888-ASK-USGS
}

\begin{abstract}
Any use of trade, product, or firm names is for descriptive purposes only and does not imply endorsement by the U.S. Government.

Although this report is in the public domain, permission must be secured from the individual copyright owners to reproduce any copyrighted materials contained within this report.
\end{abstract}

Suggested citation:

Tillery, Anne, and Eggleston, J.R., 2012, Survey of hydrologic models and hydrologic data needs for tracking flow in the Rio Grande, north-central New Mexico, 2010: U.S. Geological Survey Scientific Investigations Report 2011-5207, $39 \mathrm{p}$. 


\section{Acknowledgments}

The authors would like to thank individuals who volunteered their time and knowledge of the hydrologic models surveyed during interviews on the models. Surface-water-model interviews were conducted with Marc Sidlow, Darrell Eidson, and Ryan Gronewold of the U.S. Army Corps of Engineers, Nabil Shafike of the New Mexico Interstate Stream Commission, and Vince Tidwell and Jesse Roach of Sandia National Laboratories. Groundwater-model interviews were conducted with Peggy Barroll of the New Mexico Office of the State Engineer, Maryanne Wasiolek of Hydroscience Associates, Inc., Bruce Robinson of Los Alamos National Laboratory, Nabil Shafike of the New Mexico Interstate Stream Commission, and Steve Finch of John Shomaker and Associates.

Doug McAda and D. Michael Roark, hydrologists with the U.S. Geological Survey (USGS), were interviewed for their working knowledge of the hydrologic models. David Bjerklie of the USGS was very helpful in the survey of several surface-water models. 



\section{Contents}

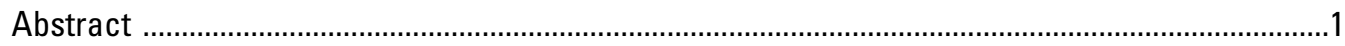

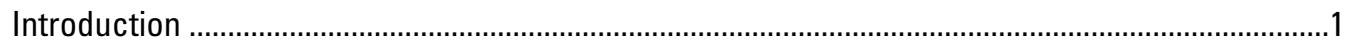

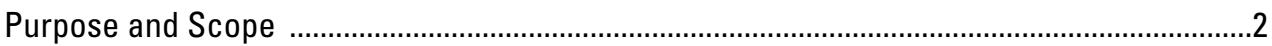

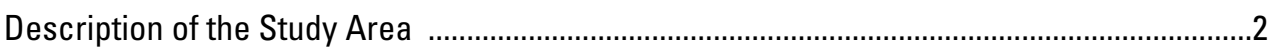

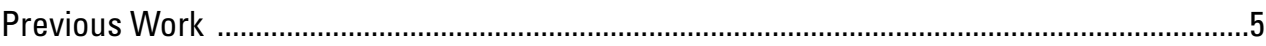

Methods Used To Survey Hydrologic Models and Assess Data Needs .........................................6

Gains and Losses Identified ..............................................................................................

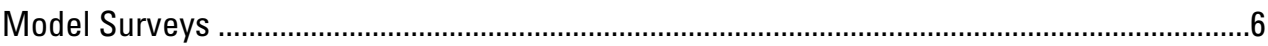

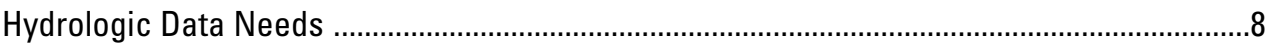

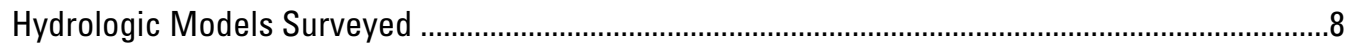

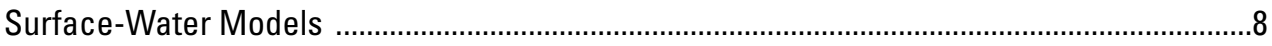

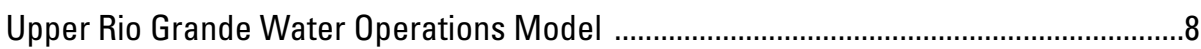

The Upper Rio Grande Simulation Model ................................................................

The Middle Rio Grande Conservancy District Decision Support System .....................10

The Middle Rio Grande FLO-2D Flood Routing Model ...............................................

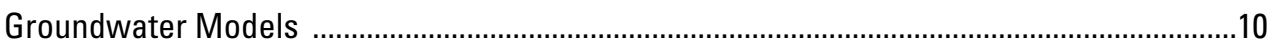

Model 1: Hearne (1985a) Mathematical Model of the Tesuque Aquifer System Near Pojoaque, New Mexico ..............................................................................11

Model 2: Kernodle and Scott (1986) Three-Dimensional Model Simulation of Steady-State Ground Water Flows in the Albuquerque-Belen Basin, New Mexico

Model 3: Kernodle and others (1987) Three-Dimensional Model Simulation of Transient Ground-Water Flow in the Albuquerque-Belen Basin, New Mexico

Model 4: McAda and Wasiolek (1988) Simulation of the Regional Geohydrology of the Tesuque Aquifer System near Santa Fe, New Mexico

Model 5: McAda (1990) Simulation of the Effects of Ground-Water Withdrawal from a Well Field Adjacent to the Rio Grande, Santa Fe County, New Mexico

Model 6: Frenzel (1995) Geohydrology and Simulation of Ground-Water Flow near Los Alamos, North-Central New Mexico

Model 7: Kernodle and others (1995) Simulation of Ground-Water Flow in the Albuquerque Basin, Central New Mexico, 1901-1994, with Projections to 2020 ....

Model 8: Tiedeman and others (1998) Application of Nonlinear-Regression Methods to a Ground-Water Flow Model of the Albuquerque Basin, New Mexico

Model 9: Barroll (2001) Documentation of the Administrative Groundwater Model for the Middle Rio Grande Basin

Model 10: McAda and Barroll (2002) Simulation of Ground-Water Flow in the Middle Rio Grande Basin Between Cochiti and San Acacia, New Mexico ......13

Model 11: Sanford and others (2003) Use of Environmental Tracers To Estimate Parameters for a Predevelopment Ground-Water Flow Model of the Middle Rio Grande Basin, New Mexico 
Model 12: Keating and others (2005) Development and Application of Numerical Models To Estimate Fluxes Through the Regional Aquifer Beneath the Pajarito Plateau

Model 13: MacClune and others (2006) High-Resolution Groundwater Models for the Assessment of Riparian Restoration Options and River Conveyance Efficiency

Model Surveys .

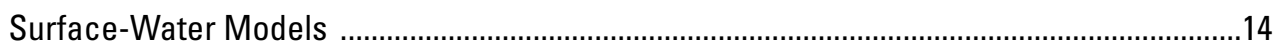

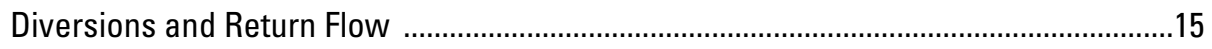

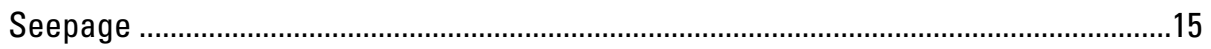

Changes in Reservoir Storage ...............................................................................

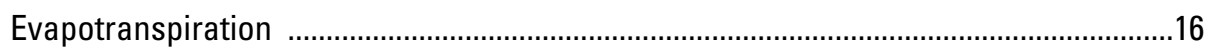

Elements Not Addressed by Surface-Water Models ...................................................16

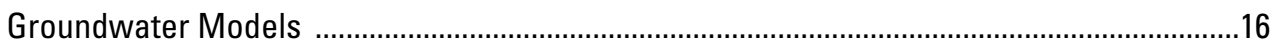

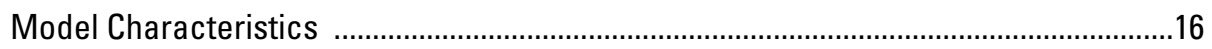

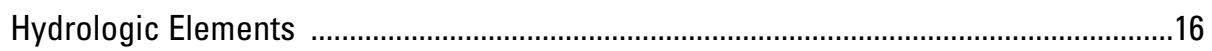

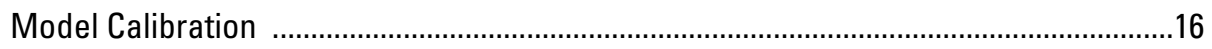

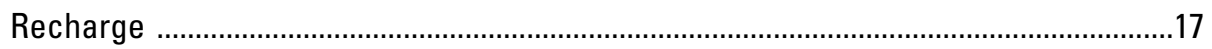

Surface-Water/Groundwater Interaction ....................................................................17

Hydrologic Data Needs for Tracking Flow on the Rio Grande ...................................................17

Model Ability To Track Flow ....................................................................................................

Surface-Water Models ...............................................................................................18

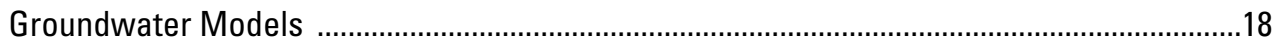

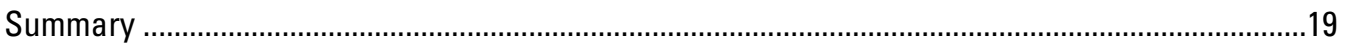

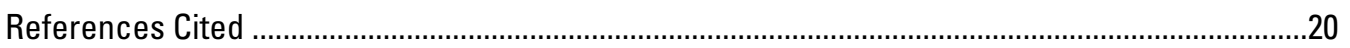

\section{Figures}

1. A, Rio Grande Basin from headwaters in southern Colorado to Elephant Butte Reservoir, New Mexico ...............................................................................................

$B$, Detail from $1 A$ showing stream network ...............................................................

2. Conceptual model diagrams. $A$, Generalized surface-water conceptual model. $B$, Generalized groundwater conceptual model ..............................................................

3. Generalized geographic extent of the surveyed groundwater models ..........................12

\section{Tables}

1. General characteristics of the surveyed surface-water models

2. Summary of treatments of hydrologic elements by the surveyed surface-water models

3. Characteristics and hydrologic elements of the surveyed groundwater models ..........30

4. Well fields included in each groundwater model ..........................................................3

5. Factors used by each surveyed groundwater model to simulate recharge ....................36

6. Methods used for modeling surface-water/groundwater interactions in the groundwater models surveyed 


\section{Conversion Factors}

\section{Inch/Pound to SI}

\begin{tabular}{|c|c|c|}
\hline Multiply & By & To obtain \\
\hline \multicolumn{3}{|c|}{ Length } \\
\hline inch (in.) & 2.54 & centimeter $(\mathrm{cm})$ \\
\hline inch (in.) & 25.4 & millimeter $(\mathrm{mm})$ \\
\hline foot $(\mathrm{ft})$ & 0.3048 & meter $(\mathrm{m})$ \\
\hline mile (mi) & 1.609 & kilometer $(\mathrm{km})$ \\
\hline \multicolumn{3}{|c|}{ Area } \\
\hline acre & 4,047 & square meter $\left(\mathrm{m}^{2}\right)$ \\
\hline acre & 0.4047 & hectare (ha) \\
\hline acre & 0.4047 & square hectometer $\left(\mathrm{hm}^{2}\right)$ \\
\hline acre & 0.004047 & square kilometer $\left(\mathrm{km}^{2}\right)$ \\
\hline square mile $\left(\mathrm{mi}^{2}\right)$ & 259.0 & hectare (ha) \\
\hline square mile $\left(\mathrm{mi}^{2}\right)$ & 2.590 & square kilometer $\left(\mathrm{km}^{2}\right)$ \\
\hline \multicolumn{3}{|c|}{ Flow rate } \\
\hline cubic foot per second $\left(\mathrm{ft}^{3} / \mathrm{s}\right)$ & 0.02832 & cubic meter per second $\left(\mathrm{m}^{3} / \mathrm{s}\right)$ \\
\hline
\end{tabular}

Vertical coordinate information is referenced to the National Geodetic Vertical Datum of 1929 (NGVD 29).

Horizontal coordinate information is referenced to the North American Datum of 1988 (NAD 88). Altitude, as used in this report, refers to distance above the vertical datum. 



\title{
Survey of Hydrologic Models and Hydrologic Data Needs for Tracking Flow in the Rio Grande, North-Central New Mexico, 2010
}

\author{
By Anne Tillery and Jack R. Eggleston
}

\section{Abstract}

The six Middle Rio Grande Pueblos have prior and paramount rights to deliveries of water from the Rio Grande for their use. When the pueblos or the Bureau of Indian Affairs Designated Engineer identifies a need for additional flow on the Rio Grande, the Designated Engineer is tasked with deciding the timing and amount of releases of prior and paramount water from storage at El Vado Reservoir to meet the needs of the pueblos. Over the last three decades, numerous models have been developed by Federal, State, and local agencies in New Mexico to simulate, understand, and (or) manage flows in the Middle Rio Grande upstream from Elephant Butte Reservoir. In 2008, the Coalition of Six Middle Rio Grande Basin Pueblos entered into a cooperative agreement with the U.S. Geological Survey to conduct a comprehensive survey of these hydrologic models and their capacity to quantify and track various components of flow. The survey of hydrologic models provided in this report will help water-resource managers at the pueblos, as well as the Designated Engineer, make informed water-resource-management decisions that affect the prior and paramount water use. Analysis of 4 publicly available surface-water models and 13 publicly available groundwater models shows that, although elements from many models can be helpful in tracking flow in the Rio Grande, numerous data gaps and modeling needs indicate that accurate, consistent, and timely tracking of flow on the Rio Grande could be improved.

Deficient or poorly constrained hydrologic variables are sources of uncertainty in hydrologic models that can be reduced with the acquisition of more refined data. Data gaps need to be filled to allow hydrologic models to be run on a real-time basis and thus ensure predictable water deliveries to meet needs for irrigation, domestic, stock, and other water uses. Timeliness of flow-data reporting is necessary to facilitate real-time model simulation, but even daily data are sometimes difficult to obtain because the data come from multiple sources.

Each surface-water model produces results that could be helpful in quantifying the flow of the Rio Grande, specifically by helping to track water as it moves down the channel of the Rio Grande and by improving the understanding of river hydraulics for the specified reaches. The ability of each surface-water model to track flow on the Rio Grande varies according to the purpose for which each model was designed. The purpose of Upper Rio Grande Water Operations Model (URGWOM) - to simulate water storage and delivery operations in the Rio Grande-is more applicable to tracking flow on the Rio Grande than are any of the other surface-water models surveyed. Specifically, the strengths of URGWOM in relation to modeling flow are the details and attention given to the accounting of Rio Grande flow and San Juan-Chama flow at a daily time step. The most significant difficulty in using any of the surveyed surface-water models for the purpose of predicting the need for requested water releases is that none of the surface-water models surveyed consider water accounting on a real-time basis.

Groundwater models that provide detailed simulations of shallow groundwater flow in the vicinity of the Rio Grande can provide large-scale estimates of flow between the Rio Grande and shallow aquifers, which can be an important component of the Rio Grande water budget as a whole. The groundwater models surveyed for this report cannot, however, be expected to provide simulations of flow at time scales of less than the simulated time step (1 month to 1 year in most cases). Of those of the currently used groundwater models, the purpose of model 13 - to simulate the shallow riparian groundwater environment - is the most appropriate for examining local-scale surface-water/groundwater interactions. The basin-scale models, however, are also important in understanding the large-scale water balances between the aquifers and the surface water. In the case of the Upper and Middle Rio Grande Valley, models 6, 10, and 12 are the most accurate and current groundwater models available.

\section{Introduction}

The Coalition of Six Middle Rio Grande Basin Pueblos in New Mexico would like to ensure predictable water deliveries to meet their needs for irrigation, domestic, stock, and other water uses at the six pueblos. The six Middle Rio Grande 
Basin Pueblos are Native American tribes whose lands are located on the main stem of the Rio Grande downstream from the U.S. Geological Survey (USGS) Rio Grande at Otowi stream-gaging station (fig. 1) and are within the Middle Rio Grande Conservancy District (MRGCD) service area, which extends from below Cochiti Lake downstream to the northern boundary of the Bosque del Apache National Wildlife Refuge (Oad and others, 2009). From north to south, the six Middle Rio Grande Basin Pueblos include the Pueblos of Cochiti, Santo Domingo (Kewa), San Felipe, Santa Ana, Sandia, and Isleta (fig. 1).

The pueblos' rights to deliveries of water from the Rio Grande are based on laws spanning multiple centuries and multiple crowns (Mann, 2007). The pueblos' "prior and paramount" rights to water deliveries were recognized by the act of March 13, 1928 (45 Stat. 312) (hereafter, the act). The act authorized the Secretary of the Interior to execute an agreement with the MRGCD providing for, among other things, conservation, irrigation, drainage, and flood control for the Pueblo Indian lands in the Rio Grande Valley, New Mexico (Sanchez, 2007). A quantity of water based on historically irrigated pueblo acreage - called prior and paramount water - is stored at El Vado Reservoir (fig. 1) each year to be delivered when needed to the pueblos. Storage and release of water for the six Middle Rio Grande Pueblos have taken place at El Vado Reservoir since the reservoir was first used in 1935 (Sanchez, 2007). Procedures for the storage and release of prior and paramount water were outlined and agreed upon in a December 28, 1981, agreement titled "Procedures for the Storage and Release of Indian Water Entitlements of the Six Middle Rio Grande Pueblos, Between the Six Middle Rio Grande Pueblos and the Department of Interior" (Chemanji Shu-Nyamboli, written commun., Hydrologist, Pueblo of San Felipe, Sept. 2011). An analysis of the policies and procedures relating to calculations of storage and release of prior and paramount water is not addressed in this report.

The prior and paramount water is delivered as a parcel of water along the Rio Grande and then through the MRGCD's diversions and canal system. The Secretary of the Interior through the Bureau of Indian Affairs has designated a technical expert, called the Designated Engineer, to oversee the delivery of prior and paramount water to the pueblos, among other tasks.

When the pueblos identify a need for prior and paramount water releases, the Designated Engineer is responsible for deciding the timing and amount of releases of prior and paramount water to meet the needs of the pueblos. Deliveries of prior and paramount water that occur too late or that are of insufficient quantity may be unusable by the pueblos. The challenge to the pueblos and the Designated Engineer is to know, with sufficient warning time, when steamflows in the Rio Grande will become too low for the pueblos' needs and to correctly estimate timing and volume of prior and paramount water releases from El Vado Reservoir so that the release will fulfill the needs of the pueblos.

Over the last three decades, numerous hydrologic models have been developed by Federal, State, and local agencies in
New Mexico to simulate, understand, and (or) manage flows of the Rio Grande upstream from Elephant Butte Reservoir. None of these models were developed specifically to manage prior and paramount water; however, certain elements within some or all of the models that can account for or quantify and track various hydrologic elements might be applicable to the management of prior and paramount waters and therefore helpful to the pueblo water-resource managers and the Designated Engineer. In 2008, the Coalition of Six Middle Rio Grande Basin Pueblos entered into a cooperative agreement with the USGS to conduct a comprehensive survey of these hydrologic models and their capacity to quantify and track various components of flow. The survey of hydrologic models provided in this report will help water-resource managers at the pueblos, as well as the Designated Engineer, make informed water-resource-management decisions that affect the prior and paramount water use.

\section{Purpose and Scope}

This report provides a detailed survey of selected hydrologic models in the form of comparison tables to be used as tools to help readers evaluate the models for multiple uses, including tracking of flow on the Rio Grande. The report also includes discussion of hydrologic data that are not yet being collected but would be useful in facilitating a more accurate accounting of water in the Rio Grande. Hydrologic elements that can be accounted by the hydrologic models can include stored water, tributary inflow, intermountain transfer water, prior and paramount water, or any other specified flow to be accounted or tracked along the Rio Grande. The hydrologic models surveyed for this report are all publicly available surface-water or groundwater models covering some portion of the reach of the Rio Grande and its tributaries from the Rio Grande at Embudo, New Mexico, downstream to Isleta Pueblo, New Mexico.

The areal extents of surface-water models surveyed in this report were from the Rio Grande at Embudo, New Mexico, stream-gaging station to a diversion structure at Isleta Pueblo (figs. $1 A$ and $1 B$ ). The areal extents of groundwater models surveyed were from the Rio Grande at Otowi streamgaging station to Elephant Butte Reservoir (fig. 1A). Some of the models surveyed have areal extents that are beyond the study area; however, only the portions of those models that are within the study area were surveyed. The models' documentations were acquired, and the assumptions and dependencies upon which these models are based are presented in this report. Because documentation for each model is available to the public, indepth descriptions of model processes are not included in this report.

\section{Description of the Study Area}

The study area encompasses the Rio Grande, its valley, and major tributaries in north-central New Mexico from the USGS stream-gaging station on the Rio Grande at Embudo 
$\boldsymbol{A}$
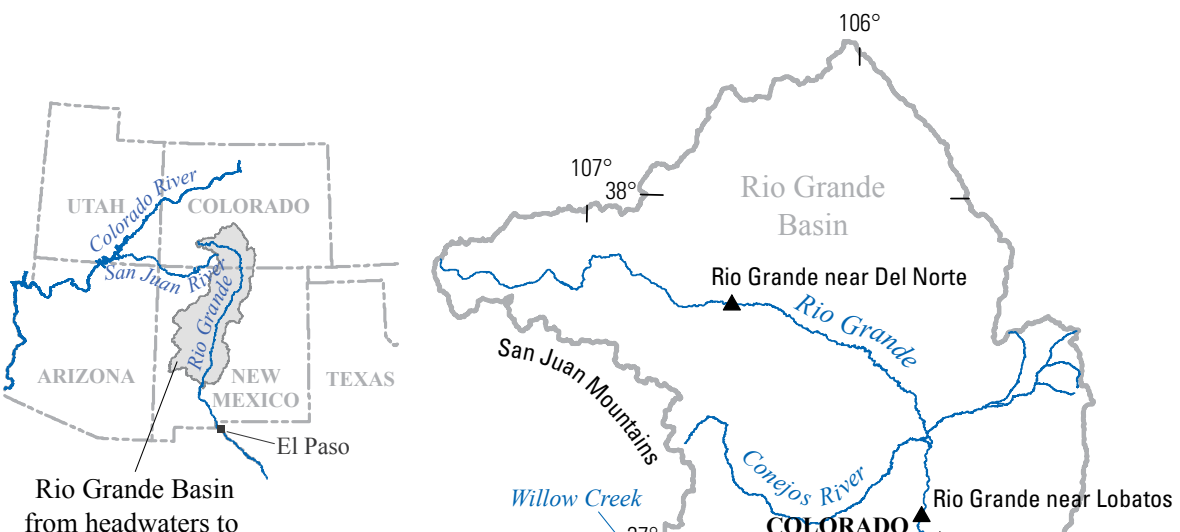

Rio Grande Basin
from headwaters to

Elephant Butte, New Mexico
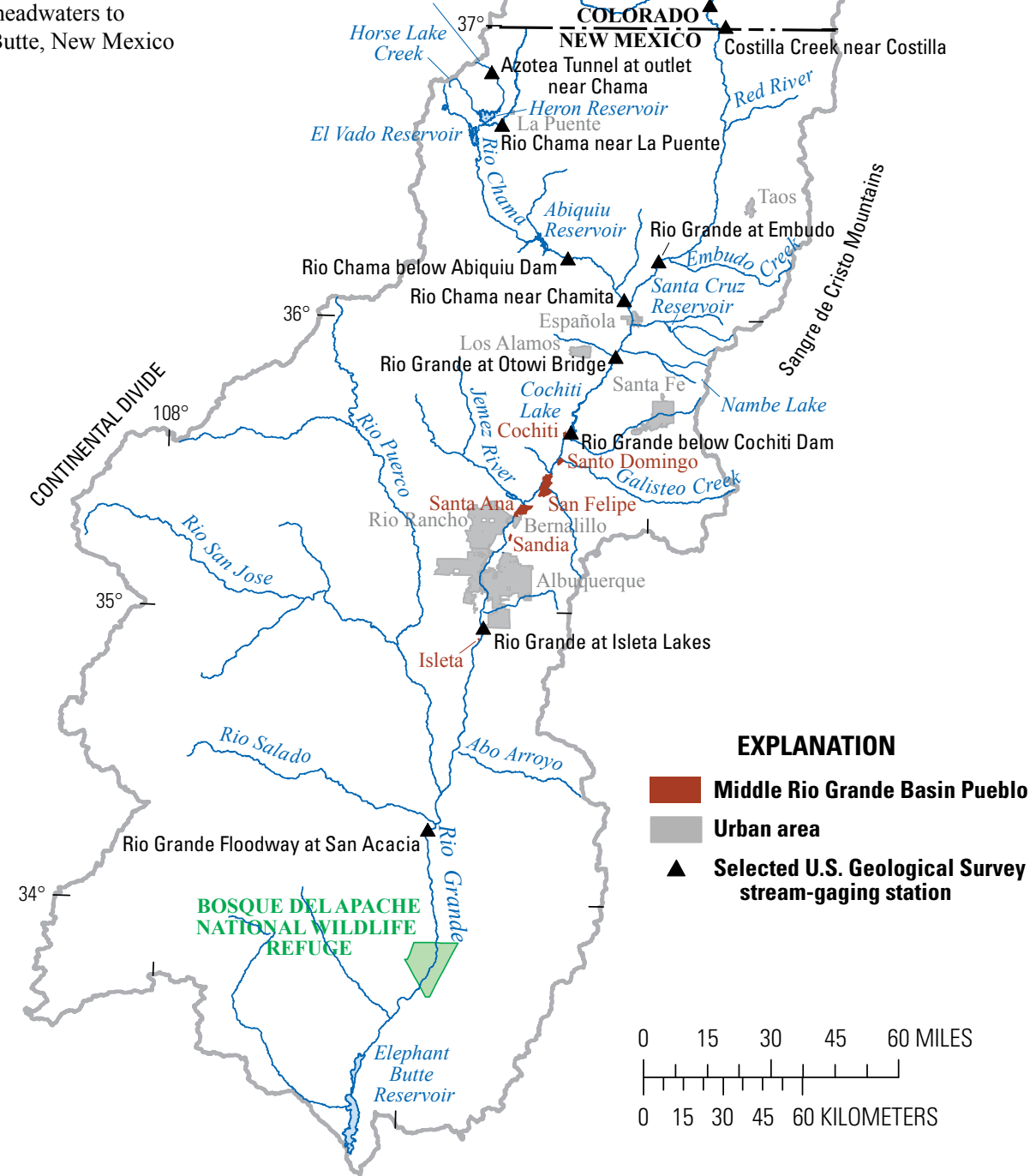

Base from U.S. Geological Survey digital data, 2000, 1:24,000

Universal Transverse Mercator, zone 13

North American Datum of 1988

Figure 1. A, Rio Grande Basin from headwaters in southern Colorado to Elephant Butte Reservoir, New Mexico. B, Detail from $1 A$ showing stream network. 


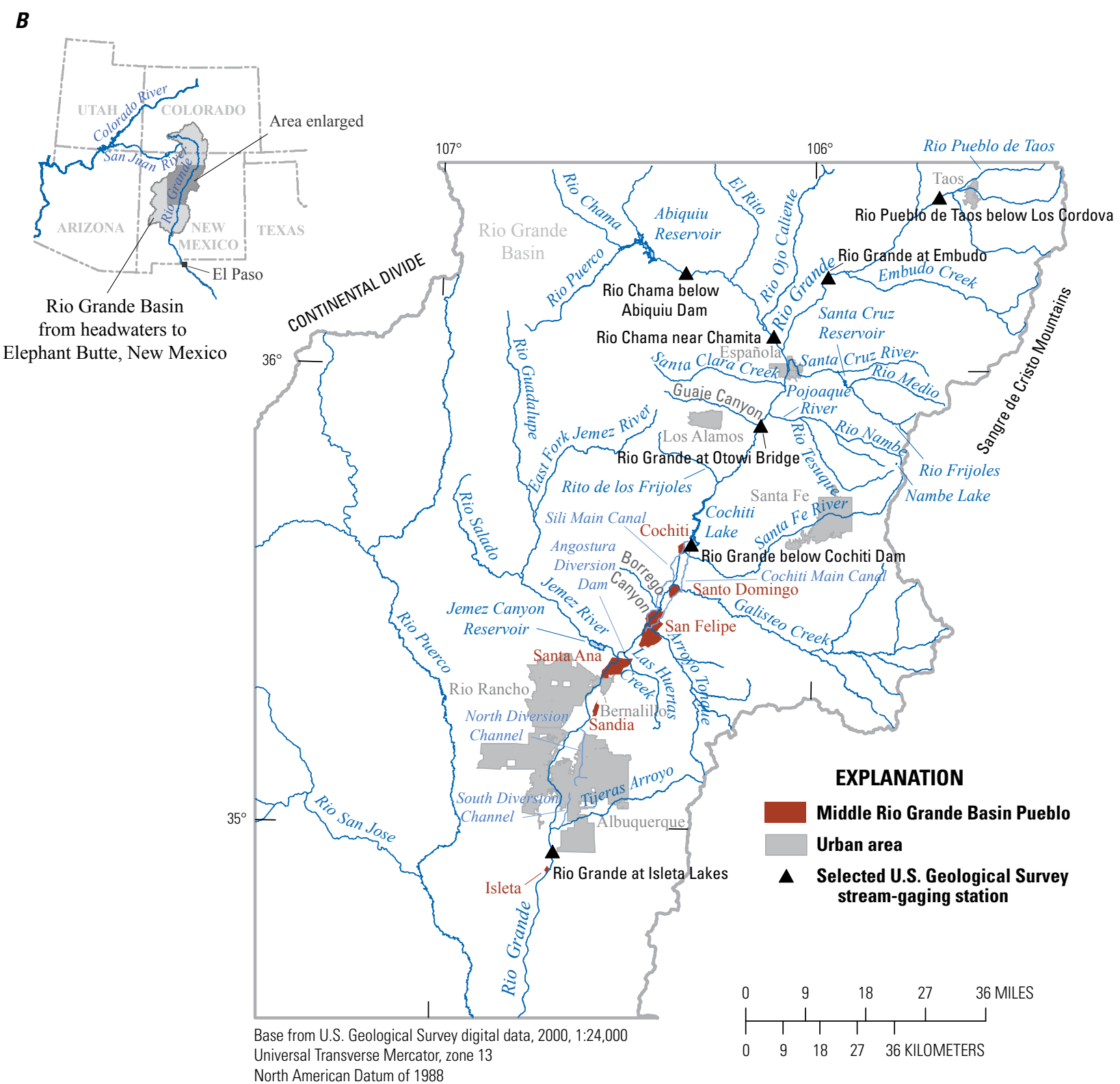

Figure 1. A, Rio Grande Basin from headwaters in southern Colorado to Elephant Butte Reservoir, New Mexico. B, Detail from $1 A$ showing stream network.-Continued

downstream to the diversion at Isleta Pueblo south of Albuquerque (figs. $1 A$ and $1 B$ ). For the purposes of this report the terms "Upper Rio Grande Valley" and "Middle Rio Grande Valley" refer to the geographic location of the Rio Grande within the State of New Mexico. "Upper Rio Grande" generally refers to the Rio Grande north of Cochiti Lake (fig. 1B) (although two of the models surveyed include the word "upper" in their titles and have geographic domains that extend some distance south of Cochiti Lake). "Middle" refers to the section of the Rio Grande roughly between Cochiti Lake and Elephant Butte Reservoir.
At the Rio Grande at Embudo stream-gaging station, the drainage area of the Rio Grande is 10,400 square miles $\left(\mathrm{mi}^{2}\right)$ with 7,460 $\mathrm{mi}^{2}$ contributing to the flow of the Rio Grande. Internally drained basins such as playas and the closed basin in Colorado make up the difference between noncontributing and contributing areas in the watershed. The elevation of the gage at Embudo is 5,789 feet (ft) above the National Geodetic Vertical Datum of 1929 (NGVD 29). At Isleta, the drainage area is $17,666 \mathrm{mi}^{2}$ with $14,626 \mathrm{mi}^{2}$ contributing to the flow of the Rio Grande. The elevation of the gage at Isleta is $4,870 \mathrm{ft}$ (NGVD 29). Precipitation for the study area ranges 
from 45 inches annually at the higher elevations of the Sangre de Cristo Mountains at the headwaters of Embudo Creek to 9 inches annually in the lower elevations of the study area around Albuquerque (PRISM Climate Group, 2009). The river reaches specified in this study include five reservoirs:

- Heron Reservoir on Willow Creek, a tributary to the Rio Chama,

- El Vado Reservoir on the Rio Chama,

- Abiquiu Reservoir on the Rio Chama,

- Jemez Canyon Reservoir on the Jemez River, and

- Cochiti Lake on the Rio Grande (figs. $1 A$ and $1 B$ ).

Two small reservoirs, Nambe Lake and Santa Cruz Reservoir, are on tributaries of the Rio Grande near the City of Española (fig. 1B). Many of the tributaries to the Rio Chama and Rio Grande are ephemeral, flowing only in response to precipitation events or snowmelt in the higher elevations.

The alluvial basins in the study area formed as a result of extension associated with the Rio Grande Rift. The basins are bounded by faults and are filled with sediment derived locally from adjacent uplifted areas and from upstream basins to the north. The total thickness of the basin fill may be in excess of $15,000 \mathrm{ft}$ in some locations (Kernodle, 1992). Most basins in New Mexico are shallower, with 2,000-3,000 ft of basin fill being the most common range (Kernodle, 1992). The fill material is identified as the Santa Fe Group of the Cenozoic Era, which is generally unconsolidated and consists of fine-grained playa and lacustrine deposits, alluvial fan conglomerates, eolian fine sands, fluvial gravels, and occasional lava flows and ash deposits (Kernodle, 1992).

The northwestern and eastern boundaries of the upper Rio Grande system are defined by the San Juan and Sangre de Cristo Mountains, respectively. These mountains also provide snowmelt, a primary source of runoff, to the river system. In north-central and northwestern New Mexico, the upper Rio Grande and Rio Chama valleys are entrenched in deep, narrow canyons. Agricultural development along these reaches is limited by the narrow width of the flood plains on the canyon floors. In this reach, the Rio Grande tends to gain water from mountain-front recharge and tributary inflows faster than the water is lost to the atmosphere or to human or agricultural consumption, resulting in a net gain in flow (Roach, 2007). Between the Rio Grande at Otowi stream-gaging station and Cochiti Lake, the river is entirely entrenched in deep canyons and there is no flood plain to speak of.

Downstream from Cochiti Lake, the Middle Rio Grande Valley becomes shallower and begins to widen. The flood plain reaches widths of up to 5 miles (mi) downstream from Isleta Pueblo. The increased width of the flood plain is accompanied by an increase in agricultural development downstream from Cochiti Lake. Agricultural development continues southward until it is replaced by the urban development of the Albuquerque metropolitan area; south of Albuquerque, agricultural development continues. In 2010, the combined population of the cities of Albuquerque $(545,852$ people) and nearby Rio Rancho (87,521 people) made up nearly 31 percent of the population of the entire State of New Mexico (U.S. Census Bureau, 2010). Flow in the Rio Grande decreases between Cochiti Lake and Albuquerque. Irrigation diversions, evapotranspiration, and seepage losses to groundwater are the primary factors that reduce flow in this reach of the Rio Grande (Kernodle, 1992). The potential annual evapotranspiration rate alone can be as much as $6 \mathrm{ft}$ of water per year (Kernodle, 1992), particularly in the riparian areas in proximity to the Rio Grande. Historical accounts indicate that the Rio Grande would frequently cease to flow by the time it got to the Mesilla Basin upstream from El Paso, Texas, until reservoirs began to be constructed in the early 1900s (Kernodle, 1992).

Riverside drains and levees run along both banks of the Rio Grande starting a few miles south of the diversions at Cochiti Lake and continuing intermittently as far south as Elephant Butte Reservoir (Oad and others, 2009). The locations of the riverside drains range from several hundred to several thousand feet from the river. The drains are designed to intercept shallow groundwater resulting from irrigation return flow and river seepage. By intercepting this shallow groundwater, the drains function to keep the ground surface surrounding the river from becoming saturated. Intercepted groundwater is funneled back to the river downstream through the drains.

Colorado River water is delivered to users along the Rio Grande by the San Juan-Chama Project (Oad and others, 2009). The San Juan-Chama project takes water from the San Juan River Basin, a tributary of the Colorado River, and diverts it under the Continental Divide into the Rio Grande Basin by use of $27 \mathrm{mi}$ of tunnels. The diverted water from the Azotea Tunnel discharges into a tributary of the Rio Chama upstream from Heron Reservoir. Water that is transported from the San Juan River Basin to the Rio Grande Basin by way of intermountain tunnels is locally referred to as the "San JuanChama water" or "SJC" water.

\section{Previous Work}

Published documentation for most models includes a synopsis of previous models and reasons for the development of the new model (Roach and Tidwell, 2009; McAda and Barroll, 2002; Sanford and others, 2003). Reports have been written that compare the output of two or more models that model the same hydrogeologic setting (Reddi and others, 1990). Documents designed to compare and contrast large numbers of existing models, however, have not been developed for the Middle Rio Grande area. The only comprehensive report summarizing multiple hydrologic models including models of the Middle Rio Grande area was published by Kernodle (1992) in a study that evaluated USGS groundwaterflow models for multiple States in the Southwest. The report by Kernodle (1992) was designed to summarize the available models developed by the USGS, identify commonly simulated hydrogeologic characteristics, and isolate preferred approaches 
to simulating groundwater flow in the various basin-fill aquifer systems in Colorado, New Mexico, and Texas. The models discussed in that report that include the Middle Rio Grande Valley were Hearne (1985a, 1985b), Reeder and others (1967), and Kernodle and Scott (1986).

\section{Methods Used To Survey Hydrologic Models and Assess Data Needs}

All publicly available surface-water and groundwater models, including those that model surface-water/groundwater interactions that have been developed for the Rio Grande within the study area, were identified and surveyed for this study. The models were surveyed by using comprehensive lists of hydrologic elements identified by generalized conceptual models developed for this study. Data needs identified during the model-survey process were documented to facilitate improvements in future data-collection activities.

\section{Gains and Losses Identified}

Generalized conceptual models that include the substantial gains and losses of water that affect the amount of water in those systems were constructed for both the surface-water and groundwater systems (fig. 2). In the surface-water conceptual model, hydrologic gains are characterized as inflows to the surface-water channel, and losses are characterized as outflows (fig. $2 A$ ). In the groundwater conceptual model, hydrologic gains are characterized as recharge to the aquifer, and losses are characterized as discharge from the aquifer (fig. $2 B$ ).

In general, hydrologic gains to a surface-water body such as a river can be divided into the naturally occurring gains such as rainfall runoff, snowmelt runoff, seepage gains, tributary contributions, and springs and the human-induced gains such as effluent/irrigation return and intermountain transfer of water (for example, the water transferred from the San Juan River Basin to the Rio Grande Basin). Hydrologic losses to a surface-water body also occur naturally or by human induction. Examples of naturally occurring hydrologic losses from a surface-water body are evapotranspiration and seepage loses. Human-induced losses from a surface-water body include diversions of water for municipal or irrigation use. Diversions on the Rio Grande downstream from the Rio Chama can involve Rio Grande water or San Juan-Chama water. Water that is stored in reservoirs and later released creates a humaninduced hydrologic gain to the river downstream at the time of the release. When the volume of water in storage in a reservoir is increased, a human-induced hydrologic loss occurs in the river downstream. The distinction between naturally occurring and human induced, as applied to hydrologic gains or losses, is required for tracking or "accounting" natural flow in a river. "Natural flow" is a term that is commonly used among hydrologists, ecologists, and persons with an interest in water rights. Although there is no single accepted definition, natural flow is generally accepted as the flow that would have passed a certain point in a stream without upstream human intervention.

Hydrologic gains and losses affecting aquifers also can be characterized as naturally occurring or human induced. An example of naturally occurring hydrologic gains to an aquifer would be precipitation recharge, and an example of humaninduced gains would be seepage from drains and canals and artificial recharge (intentionally injecting surface water into an aquifer for storage [Reese, 2009]). An example of a naturally occurring hydrologic loss from an aquifer would be groundwater discharge to rivers, and a human-induced loss would be groundwater pumping for municipal or agricultural purposes.

Physical processes occurring at reservoirs involve a variety of gains and losses occurring simultaneously, such as precipitation, infiltration, evaporation, and transpiration, in addition to the storage of inflow or release of previously stored water. The net difference between the gains and losses occurring at a reservoir at any given time may vary in relation to temperature, recent precipitation patterns, or other factors. Hydrologic processes acting on the water stored in a reservoir can cause either net gains or net losses to the stored water depending on conditions. The river reaches specified in this study include

- five major reservoirs

- Heron Reservoir

- El Vado Reservoir

- Abiquiu Reservoir on the Rio Chama

- Jemez Canyon Reservoir on the Jemez River

- Cochiti Lake on the Rio Grande

- and two minor reservoirs

- the Santa Cruz Reservoir and

- Nambe Lake.

Interactions between surface water and shallow groundwater also can vacillate between net flow into or out of the surface-water body in relation to the season, temperature, or water-use patterns and are ultimately dependent on hydraulic head or stage in the surface-water body in relation to the hydraulic head in the aquifer (Winter and others, 1998). For the purpose of this survey, surface-water/groundwater interactions are characterized as seepage gains to or seepage losses from the surface-water system.

\section{Model Surveys}

The generalized conceptual models (fig. 2) were used to design a framework for comparison of model treatments of 
$\boldsymbol{A}$

- Rainfall runoff

- Snowmelt runoff

- Springs

- Tributary contributions

- Seepage gains from groundwater

- San Juan-Chama inflow*

- Effluent/irrigation return*
- Evapotranspiration/ riparian losses

- Seepage losses to groundwater

- Irrigation diversions*

- Municipal diversions*

- San Juan-Chama diversions*

CHANGES IN STORAGE

Rio Grande water

- Released from reservoir storage*

- Retained in reservoirs*

San Juan-Chama water

- Released from reservoir storage*

- Retained in reservoirs*

B

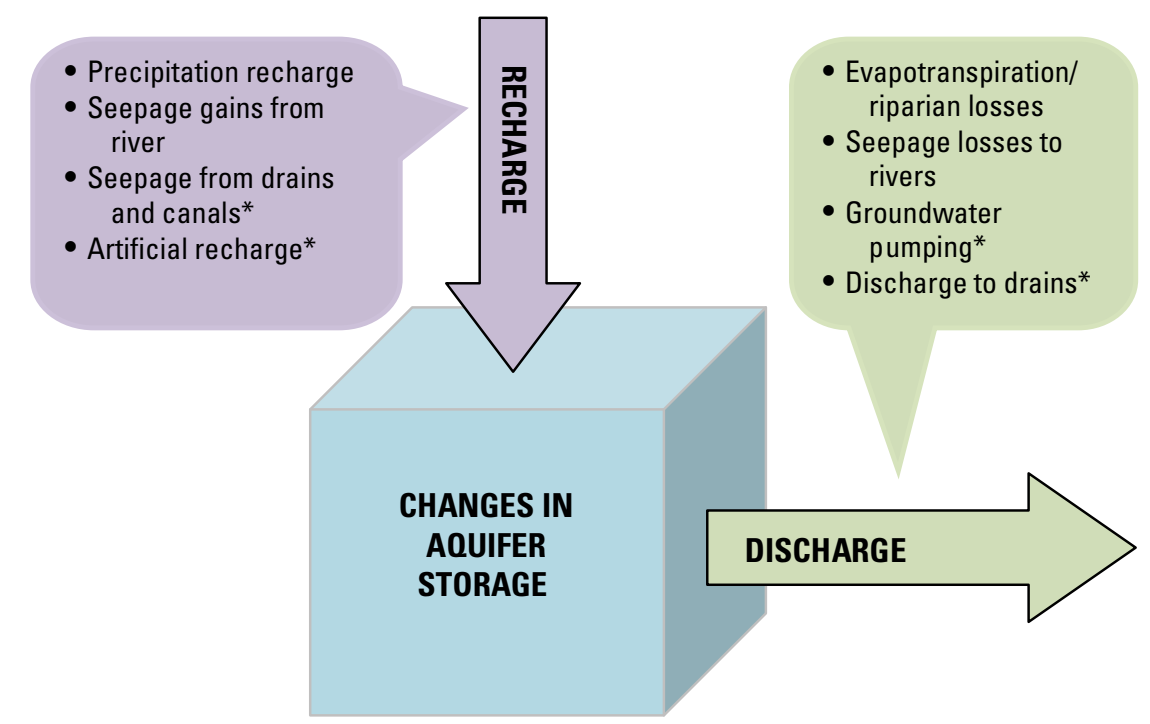

\section{EXPLANATION}

* Human induced

Note: Seepage gains or losses can be due to naturally occurring or human-induced conditions.

Figure 2. Conceptual model diagrams. $A$, Generalized surface-water conceptual model. $B$, Generalized groundwater conceptual model. 
the known gains and losses specific to the study area. Physical occurrences of the types of elements identified in the conceptual model (such as tributary inflow) were identified for the study reach on the basis of maps and interviews with pueblo personnel. In the survey, known significant tributaries in the study area are identified by name whenever possible.

Each publicly available model was surveyed for the inclusion and treatment of the various hydrologic elements identified through the use of the conceptual model. Surfacewater models and groundwater models were surveyed separately. Model characteristics such as time steps and calibration methods were included in the surveys to give readers additional information about how the individual models operate. Tabular documentation of model characteristics and model treatment of identified hydrologic elements identified provide a summary comparison of the models for each element of interest (tables $1-6$ at end of report).

The tables of detailed information on the hydrologic models (tables 1-6) can be used as tools to help readers evaluate the models for multiple uses, including accounting types of flow in the Rio Grande. The hydrologic elements presented in the surface-water hydrologic element table (table 2) are divided into three river reaches and generally presented in an upstream to downstream order, starting with inflow elements and followed by outflow elements. The three reaches are (1) the Rio Grande from Embudo to Otowi Bridge, (2) the Rio Chama, and (3) the Rio Grande from Otowi Bridge to Isleta Pueblo. A list of hydrologic elements also was designed for the groundwater resources in the study area.

Each gain and loss identified contributes to a category of water in the Rio Grande such as natural flow, stored water released, or intermountain transfer water. For example, inflow from the Azotea Tunnel would be a component of intermountain transfer water but not of natural flow. Although the tables herein do not have the hydrologic gains and losses identified as naturally occurring or human induced, each gain and loss is identified such that the user can follow those hydrologic elements of interest for their purposes.

The surveys were completed by using model documentations and interviews. Interviews were conducted with people who previously used or currently use the hydrologic models or were involved in their development. The purpose of the interviews was to get information from people most familiar with the models on the model utility and applicability in accounting or tracking types of flow in the Rio Grande.

\section{Hydrologic Data Needs}

During the course of conducting the model surveys, hydrologic data were identified that are needed to accurately account water in the Rio Grande but do not exist. Data needs were identified from a combination of (1) observations of data that were approximated in all models and (2) suggestions from authors for ways to improve upon their models or model calibrations.

\section{Hydrologic Models Surveyed}

For each model surveyed, a brief overview is provided that describes model development and purpose. The individual elements surveyed for each model are generally presented in tabular form (tables 1-6). Elements that cannot be presented in tabular form are discussed in the Model Surveys section.

\section{Surface-Water Models}

Four publicly available surface-water models were identified for this study: (1) the Upper Rio Grande Water Operations Model (URGWOM) (U.S. Army Corps of Engineers [USACE] and others 2005a, 2005b); (2) the Upper Rio Grande Simulation Model (URGSiM) (Roach, 2007); (3) the Middle Rio Grande Conservancy District Decision Support System (DSS) (Oad and others, 2009); and (4) the Middle Rio Grande FLO-2D Flood Routing Model (FLO-2D) (Tetra Tech, Inc., 2004, and Riada Engineering, Inc., 2008). Each of the models was created for different purposes by using different software packages. The two large-scale surface-water models (URGWOM and URGSiM) cover the entire reach of the Rio Grande between Embudo and Isleta Pueblo. The third model (DSS) was designed to account flow in the Rio Grande irrigation canals from Cochiti Dam downstream to the Bosque del Apache National Wildlife Refuge, south of Isleta Pueblo. The fourth model (FLO-2D) was designed to simulate the hydraulics of the Rio Grande reach from Cochiti Dam to Elephant Butte Reservoir. Although additional surface-water models have been developed for discrete sections of the Rio Grande, their limited spatial extent and design excluded them from the current survey.

The four surface-water models surveyed produce results that could be useful in quantifying the flow of the Rio Grande, specifically by tracking water as it moves down the channel of the Rio Grande and by improving the understanding of river hydraulics for the specified reaches. The applicability of each model with respect to accounting different components of flow varies according to the purpose for which each model was designed. Table 1 lists some general characteristics of the four surface-water models.

\section{Upper Rio Grande Water Operations Model}

URGWOM is one of two publicly available surfacewater models that cover the entire reach of this study. The geographic extents of URGWOM actually extend beyond the study reach. According to the URGWOM documentation, the upper Rio Grande is the reach of the Rio Grande between the Colorado-New Mexico State line and Cochiti Dam in New Mexico (USACE and others, 2005a). URGWOM was initially developed starting in 1996 through an interagency effort of six Federal agencies, including the U.S. Army Corps of Engineers (USACE), U.S. Bureau of Reclamation (USBOR), U.S. Fish 
and Wildlife Service, USGS, Bureau of Indian Affairs, and International Boundary and Water Commission. In 2007, other State and local agencies joined the effort for continuous development and improvement of the model.

URGWOM was envisioned as simulating water storage and delivery operations in the Rio Grande from its headwaters in Colorado to below Caballo Dam in southern New Mexico. The current model extents are from the Colorado-New Mexico State line to Caballo Reservoir. The model incorporates all water management rules (such as dam releases and other diversions) for managing reservoirs along the Rio Grande from the Colorado-New Mexico State line to Elephant Butte Reservoir. It simulates the physical system and tracks San Juan-Chama and Rio Grande waters separately.

There are four separate modules within URGWOM that are utilized for decision support: Planning, Forecast, Accounting, and Water Operations. The Planning module is used to simulate different operation scenarios to evaluate long-term impacts of proposed actions. The Forecast module uses hydrologic data from past records for similar years along with current forecasted runoff information provided by the Natural Resources Conservation Service (NRCS) and the National Weather Service (NWS) to compute inflows for the Water Operations and Planning modules. The Accounting and Water Operations modules are the most useful URGWOM modules for estimating and tracking prior and paramount water releases. The Accounting module can be run on a daily time step and is used to simulate year-to-date conditions and provide updated status of account storage in reservoirs and deliveries made to water users (USACE and others, 2005b). The Water Operations module is run on a daily time step to simulate forecast operations, deliveries, and resulting flows through the end of a calendar year. Output from the Water Operations module is used for determining forecasted flows and reservoir storage for annual operating plans in order to reduce waste, eliminate unnecessary reservoir spills, prevent downstream flooding, and allow effective distribution of available water supplies.

The Accounting module tracks reservoir storage and release of 20 different water user accounts starting at Heron Reservoir. The accounts modeled at Heron Reservoir include one Rio Grande water account and 19 San Juan-Chama water accounts including accounts for various counties, municipalities, tribes, recreation areas, MRGCD, and uncontracted water. Downstream from Heron Reservoir at El Vado Reservoir, the Rio Grande accounts of (1) Supplemental ESA (Endangered Species Act), (2) Rio Grande, (3) MRGCD Drought, and (4) Indian Storage (prior and paramount storage) are simulated in the model. All accounts are tracked downstream as far as Elephant Butte Reservoir or to appropriate storage or diversion locations. Diversions include the MRGCD diversions at Cochiti Dam, near San Felipe, and at Isleta and the Drinking Water Project at Albuquerque. Accounting module simulations are completed by using inputs for actual operations, whereas the Water Operations module simulations are completed by using rules for reservoir operations.
The basic inputs to URGWOM are gaged streamflows at Rio Grande near Lobatos, Colorado, and at northern tributaries of the Rio Grande including Red River, Rio Pueblo de Taos below Los Cordovas, and Embudo Creek (figs. $1 A$ and $1 B$ ). Other inputs include San Juan diversions through the Azotea Tunnel, Willow Creek, Rio Chama above El Vado Reservoir, Galisteo Creek, Jemez River, Albuquerque's North and South Diversion Channels, Tijeras Arroyo, and the Rio Puerco. The model does not incorporate or predict monsoonal precipitation variables. The model is divided into 23 total reaches: five main reaches on the Rio Chama; eight reaches on the upper Rio Grande from the Rio Grande near Lobatos, Colorado, streamgaging station to Cochiti Lake, New Mexico; six reaches on the Middle Rio Grande from Cochiti Lake to Elephant Butte Reservoir, New Mexico; and four reaches from Elephant Butte Reservoir, New Mexico, to El Paso, Texas (USACE and others 2005a).

Upstream from Cochiti Lake, URGWOM uses a variable time lag for river routing, which is based on comparisons with historical data. The variable time lag is a simplified routing method based on a relation between velocity (hence lag time) and flow. Downstream from Cochiti Lake a straight time lag is used. Tables are developed (USACE and others, 2002) that relate discharge to time lag for each river reach modeled.

Although URGWOM is primarily aimed at quantifying flow on the Rio Grande, it also incorporates surface-water/ groundwater interaction in two ways. The Middle Rio Grande portion of the model contains a shallow groundwater component that is three cells wide for each of the 21 subreaches of the 6 river reaches modeled. The three cells represent the right and left flood-plain areas, with widths ranging from $0.1 \mathrm{mi}$ to nearly $3 \mathrm{mi}$, and the area directly below the river channel, extending to the riverside drains and with a width of about $0.5 \mathrm{mi}$. Each cell is 5-7 mi long. The purpose of including this shallow groundwater component is to capture the head-dependent flux between the river and the shallow aquifer, which is based on difference in head and a conductance term. The deep aquifer groundwater head values calculated by the McAda and Barroll (2002) regional groundwater model are inputs to the groundwater simulation in URGWOM.

\section{The Upper Rio Grande Simulation Model}

URGSiM is the second of two models that cover the entire reach of the study area and continue south of Elephant Butte Reservoir. URGSiM is an integrated climate, hydrologic, groundwater, and socioeconomic model of the upper Rio Grande that serves as a future water-planning decision support tool. URGSiM was funded by Sandia National Laboratory and created through a cooperative effort with the URGWOM technical committee. Additional funding provided by the USACE and the USBOR allow for continual updates to the model. 
URGSiM is a monthly time step Powersim (http://www. powersim.com) model that employs a system dynamics computational technique. It is a water-balance model that dynamically integrates surface-water, reservoir operations, water demand, and groundwater models for the entire New Mexico reach of the Rio Grande. The model uses data recorded from 1975 through 1999 for calibration, uses data recorded from 2000 through 2004 for validation, and then runs forward from 2005 in a scenario-evaluation mode (Roach, 2007).

URGSiM simulates groundwater with coarsely gridded variants of the regional groundwater model by McAda and Barroll (2002), the Española Basin model by Frenzel (1995), and a Socorro Basin model by Shafike (2005). Reservoir operations and water demand are also integrated into the URGSiM model. Groundwater contributions are determined by the coarsely gridded groundwater model as adapted and integrated in URGSiM. Surface-water contribution is determined by streamflow gages, and mass balance is closed by ungaged surface-water inflows and crop consumption.

URGSiM runs well on a personal computer and is designed to be a rapid screening tool for use in stakeholder outreach for water-resource planning and management decisions. It was designed so that it could be operated in support of URGWOM. URGSiM is designed to be consistent with URGWOM regarding model structure, physical processes, operations rules, equations, and inputs. Basic inputs to URGSiM include total gaged surface-water flows at the upstream model boundary, monthly climate data, human groundwater extraction and wastewater returns, and agricultural and riparian areas by plant type. It does not incorporate rainfall runoff or snowmelt relations. URGSiM is divided into 17 surface water reaches and 79 groundwater cells based on the locations of available stream-gaging stations. The reaches between Embudo and Isleta are covered by 10 of these surface-water reaches and 50 of the groundwater cells.

\section{The Middle Rio Grande Conservancy District Decision Support System}

The Middle Rio Grande Conservancy District DSS was developed during 2004 and 2005 through cooperative work between the New Mexico Interstate Stream Commission, Colorado State University, and the MRGCD. The purpose of the DSS is to help water managers and farmers determine when, how often, and for how long to irrigate in an effort to better serve farmers and their crops for more efficient use of water. The DSS can be updated and linked directly to water releases. The DSS does not allow for simulation of flow in the Rio Grande but does allow for water in the MRGCD canal system to be simulated. Because the DSS does not simulate flow in the Rio Grande, many of the elements identified in the hydrologic element table are not applicable.
The DSS uses a detailed simulation of the MRGCD canal system along with carefully measured and known crop data, weather data, and canal seepage losses to estimate water demand and develop water delivery schedules for the main canals and feeder channels. The DSS uses flow data for diversions and return flows that are collected by the MRGCD's real-time telemetry network. The DSS assumes that the estimated evaporation demand is representative of the study area as a whole, that seepage gain (return flow to the channel) is a fixed percentage of the water delivered, and that measurements of seepage loss to the groundwater for the canals and feeder channels are accurate and representative. Extensive collection of field data, including soil characteristics, water delivery rates, and on-farm water use, was conducted in 2008 (Oad and others, 2009) to validate the assumptions of the DSS. The model does not incorporate groundwater data.

\section{The Middle Rio Grande FLO-2D Flood Routing Model}

The Middle Rio Grande FLO-2D Flood Routing Model was developed by Tetra Tech, Inc. (2004), with the support of the U.S. Fish and Wildlife Service's Bosque Initiative Group, USACE, USBOR, and the New Mexico Interstate Stream Commission. The model is a two-dimensional, volumeconservation, flood routing model that distributes a flood hydrograph over a system of square grid elements. The model was designed to simulate river and overbank flow on the Rio Grande from Cochiti Dam to Elephant Butte Reservoir. It was initially completed with 500-ft grid spacing, but updates in 2007 reduced the grid spacing to $250 \mathrm{ft}$ (Riada Engineering, Inc., 2008). The purposes of the model are to simulate flooding, to map inundated areas and depths, to assess riverine habitat conditions, to support habitat restoration efforts, and to simulate water transport traveltime. The model operates under the assumptions that flow is one dimensional in the channel but closer to two dimensional in the flood-plain areas. Inputs and land cover characteristics can be updated. There are no groundwater inputs to the program.

Table 2 summarizes how select hydrologic gains and losses (or elements) identified are treated by each of the surface-water models evaluated. Note that the DSS and FLO-2D models do not cover the entire reach surveyed.

\section{Groundwater Models}

Rivers in the Middle Rio Grande Basin interact with groundwater. Human activity also affects exchanges between groundwater and surface water: pumping from wells brings groundwater to the surface, while irrigation and wastewater discharges can infiltrate back to groundwater. The timing, location, and rate of these exchanges between groundwater and surface water are constantly changing. Models that 
simulate groundwater flows and, in most cases, simulate surface-water/groundwater interactions were surveyed in this study. Although many of the groundwater models surveyed do simulate exchange of groundwater with the surface, none of the groundwater models can simulate overall surface-water flows. In the discussion of the models below, if a river is listed as being simulated by a model, it means that a boundary condition has been included in the model to represent the river. In these cases, flows between the river and underlying aquifer and the effects of pumping on the river are, or can be, calculated by the model. If, however, the model was not designed for the purpose of determining the effects of pumping on the rivers listed, then the model should not be used for that purpose.

Thirteen groundwater models were identified for inclusion in this study and, for the purpose of discussion in this report, are identified as models 1 through 13. The geographic extents (domains) for the models are shown in figure 3. All but one of the groundwater models evaluated, model 12, were based on the software package MODFLOW (Harbaugh and others, 2000) or a precursor to MODFLOW. The URGSiM groundwater model was not evaluated in this section because it is based on two other models that were evaluated, model 6 and model 10. Seven of the thirteen models were extended or substantially modified versions of earlier models. For example, the model developed by McAda and Barroll (2002), model 10, was built on the foundation of three earlier models (Kernodle and others, 1995; Tiedeman and others, 1998; Barroll, 2001). In general, this is a common occurrence with groundwater models and results both from the desire to have models reflect the most recent data available and from the need to adapt old models to new uses. Table 3 indicates the relations between the models.

Table 4 lists the well fields that are included in each groundwater model. The Los Alamos, Santa Fe, and Albuquerque well fields are located in or near the communities bearing those names. The Guaje well field is located in Guaje Canyon (fig. 1B). The Pajarito well field is located south of the community of Los Alamos. The Buckman well field is located several miles south of the Rio Grande at Otowi Bridge gage and on the east side of the Rio Grande.

\section{Model 1: Hearne (1985a) Mathematical Model of the Tesuque Aquifer System Near Pojoaque, New Mexico}

Hearne (1985a) developed a transient groundwater model of the Tesuque aquifer. The model was capable of simulating groundwater interactions with the Rio Grande, Santa Fe, Pojoaque, and Santa Cruz Rivers. As described by Hearne (1985a), "The model was used to simulate the response of the aquifer system to an irrigation-development plan in the Pojoaque River Basin." Modifications of this model exist but are not published or publicly available (Doug McAda, written commun., 2011).
Model 2: Kernodle and Scott (1986) ThreeDimensional Model Simulation of Steady-State Ground Water Flows in the Albuquerque-Belen Basin, New Mexico

Kernodle and Scott (1986) developed a steady-state model of the Albuquerque-Belen Basin aquifer. The model simulated flood-plain alluvium for the Rio Grande, Rio Puerco, Rio Salado, and Jemez River. The model was developed as part of the Regional Aquifer System Analysis (RASA) Program, a national research effort that studied 25 major aquifer systems across the Nation. The purpose of the model was to simulate steady-state groundwater flow conditions prior to 1960 in the Albuquerque-Belen Basin aquifer. This model was superseded by models 7 through 11 .

\section{Model 3: Kernodle and others (1987) Three- Dimensional Model Simulation of Transient Ground-Water Flow in the Albuquerque-Belen Basin, New Mexico}

Kernodle and others (1987) extended the model by Kernodle and Scott (1986) (model 2) to perform transient simulations. This effort was again part of the RASA Program, and the model was used to evaluate water budgets and pumping-induced leakage to groundwater from surface water. The model simulated transient (1907-79) groundwater flow in the Albuquerque-Belen aquifer. This model also was superseded by models 7 through 11 .

\section{Model 4: McAda and Wasiolek (1988) Simulation of the Regional Geohydrology of the Tesuque Aquifer System near Santa Fe, New Mexico}

McAda and Wasiolek (1988) developed a transient groundwater model of the Tesuque aquifer. The purpose of the model was to serve as a tool for water-resources management, specifically to simulate the effects of groundwater withdrawals on the Tesuque aquifer. The Rio Grande, Pojoaque River, Rio Tesuque, and Santa Fe River are individually simulated by the model. At the request of their cooperator, representations of geologic structure and surface-water/groundwater interactions were simplified (D. McAda, oral commun., 2010). Modified versions of this model are being used.

\section{Model 5: McAda (1990) Simulation of the Effects of Ground-Water Withdrawal from a Well Field Adjacent to the Rio Grande, Santa Fe County, New Mexico}

McAda (1990) modified the model by McAda and Wasiolek (1988) (model 4) to simulate proposed groundwater 


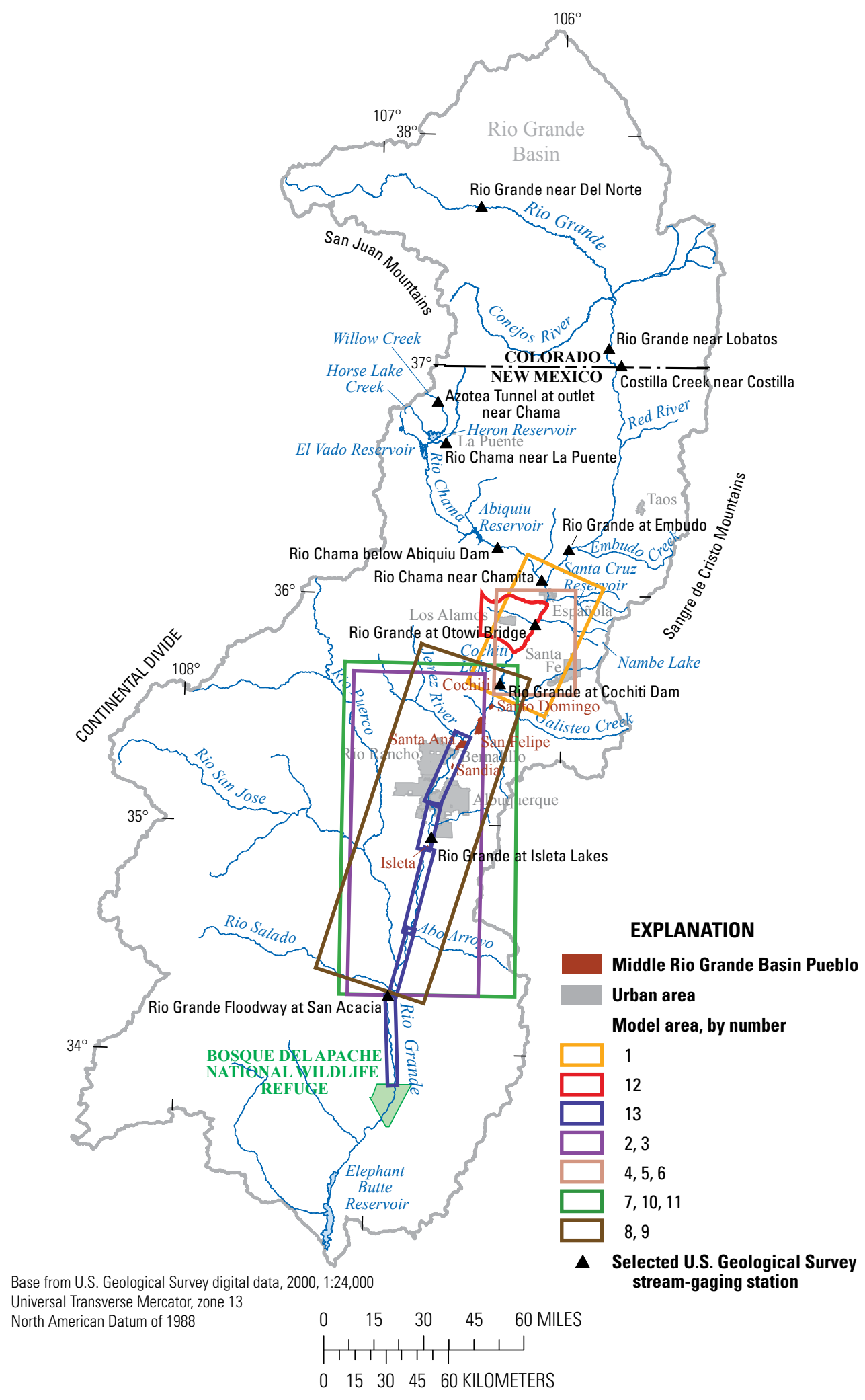

Figure 3. Generalized geographic extent of the surveyed groundwater models. 
withdrawals at the Buckman well field to supply the City of Santa Fe. The transient simulations demonstrated that the proposed pumping wells would capture water from the Rio Grande, Pojoaque River, and Tesuque River.

\section{Model 6: Frenzel (1995) Geohydrology and Simulation of Ground-Water Flow near Los Alamos, North-Central New Mexico}

Frenzel (1995) modified the McAda and Wasiolek (1988) model (model 4). Changes were made to hydraulic conductivity and storage values and to specified head boundary conditions that affected simulated recharge to the aquifer (table 4). The purpose of the model was to incorporate new geologic understanding into the Tesuque aquifer model and to compare alternative groundwater withdrawal options. The Rio Grande, Pojoaque River, Rio Tesuque, and Santa Fe River are again simulated by the model. Modified versions of this model are being used by the New Mexico Office of the State Engineer (NMOSE) and engineering consultants (P. Barroll, oral commun., May 2010).

\section{Model 7: Kernodle and others (1995) Simulation of Ground-Water Flow in the Albuquerque Basin, Central New Mexico, 1901-1994, with Projections to 2020}

Kernodle and others (1995) developed a transient groundwater model of the Albuquerque Basin to represent a new understanding of the basin hydrogeologic framework. New features of the model, as compared to Kernodle and others (1987), included a geographic information system (GIS) database to organize and facilitate changes to the model and a more detailed representation of surface-water/groundwater interactions. The authors used the model to examine a number of groundwater-withdrawal scenarios and to quantify head declines, induced recharge (surface water drawn into an aquifer by groundwater pumping), and detailed hydrologic budgets. The Rio Grande, Santa Fe River, Galisteo Creek, Tijeras Arroyo, Jemez River, Rio Puerco, Abo Arroyo, Rio Salado, and Cochiti Lake are simulated by the model along with canals and drains. Kernodle (1998) subsequently modified some of the hydraulic conductivity zones and extended the period of historical simulation by 1 year, from 1994 to 1995 . This model was computationally intensive to run and has been superseded by models 8 through 11 .

Model 8: Tiedeman and others (1998) Application of Nonlinear-Regression Methods to a GroundWater Flow Model of the Albuquerque Basin, New Mexico

Tiedeman and others (1998) applied nonlinear regression methods in modifying the model by Kernodle and others
(1995). The revised transient model had a new grid based on information learned from the previous model, an improved representation of the hydrogeology, and revised aquifer parameters that resulted in a more robust model performance. The revised model was used to simulate a variety of scenarios in which sensitivity of the most important hydraulic characteristics was quantified by direct calculation. The Rio Grande, Santa Fe River, Galisteo Creek, Tijeras Arroyo, Jemez River, Rio Puerco, Abo Arroyo, Rio Salado, and Cochiti Lake are simulated by the model. This model was designed as a research model and is not in use.

\section{Model 9: Barroll (2001) Documentation of the Administrative Groundwater Model for the Middle Rio Grande Basin}

Barroll (2001) combined one of the conceptual models from Tiedeman and others (1998) and hydraulic characteristics from Kernodle and others (1995) and Kernodle (1998) to produce a transient groundwater model for use by the NMOSE in water-resource planning. This model uses the Tiedeman and others (1998) grid, but the model hydraulic parameters are based on the Kernodle and others (1995) and Kernodle (1998) models. Modifications were made to hydraulic conductivity and specific storage values, the vertical grid discretization, and boundary conditions representing the Jemez River. The model was used to simulate stream depletions and groundwater drawdowns to support water rights in the Albuquerque Basin. The Rio Grande, Santa Fe River, Galisteo Creek, Tijeras Arroyo, Jemez River, Rio Puerco, Abo Arroyo, Rio Salado, and Cochiti Lake are simulated by the model. This model is being used by the NMOSE for water-resource planning and permitting (P. Barroll, oral commun., 2010).

\section{Model 10: McAda and Barroll (2002) Simulation of Ground-Water Flow in the Middle Rio Grande Basin Between Cochiti and San Acacia, New Mexico}

McAda and Barroll (2002) built another transient model of the Albuquerque Basin. The new model included information learned from Barroll (2001), Tiedeman and others (1998), and Kernodle and others (1995) and featured a new grid and an extension of the simulation period to the year 2000. The purpose of the model was to (1) integrate the components of the groundwater-flow system, including the hydrologic interaction between the surface-water systems in the basin; (2) better understand the geohydrology of the basin; and (3) serve as a tool for water managers to plan and administer the use of water resources in the basin. The Rio Grande, Santa Fe River, Galisteo Creek, Tijeras Arroyo, Jemez River, Rio Puerco, Abo Arroyo, Rio Salado, Cochiti Lake, and Jemez Canyon Reservoir are simulated by the model in addition to canals and drains. Although interactions with surface water are modeled with limited detail and calibration, model output represents 
a reasonable reproduction of groundwater levels and stream losses (D. McAda, oral commun., May 2010). Modified versions of this model are being used by NMOSE for waterresource planning and to set boundary conditions for model 13 and for URGWOM.

\section{Model 11: Sanford and others (2003) Use of Environmental Tracers To Estimate Parameters for a Predevelopment Ground-Water Flow Model of the Middle Rio Grande Basin, New Mexico}

Sanford and others (2003) built a steady-state model of the Albuquerque Basin and used environmental tracer and hydrochemistry data to calibrate hydraulic conductivity and recharge values. The purpose of the model was to demonstrate the use of tracers as a calibration tool and to construct an improved model. The Rio Grande, Santa Fe River, Galisteo Creek, Tijeras Arroyo, Arroyo Tonque, Jemez River, Rio Puerco, Abo Arroyo, and Rio Salado are simulated by the model. This is a steady state model with recharge calibrated on the basis of the geochemistry. The model was intended as a research model and is not in use.

\section{Model 12: Keating and others (2005) Development and Application of Numerical Models To Estimate Fluxes Through the Regional Aquifer Beneath the Pajarito Plateau}

Keating and others (2005) developed a transient groundwater model to simulate a portion of the regional Española Basin aquifer. The model's purpose was to provide new insight into large-scale aquifer properties and groundwater fluxes beneath the Pajarito Plateau in the vicinity of the Los Alamos National Laboratory. The Santa Clara River, Rito de los Frijoles, and Rio Grande are simulated in the model. This is a detailed and adaptable model, a modified version of which is currently in use at the Los Alamos National Laboratory (B. Robinson, oral commun., May 2010).

\section{Model 13: MacClune and others (2006) High- Resolution Groundwater Models for the Assessment of Riparian Restoration Options and River Conveyance Efficiency}

MacClune and others (2006) developed a set of transient groundwater models for simulating the shallow riparian environment along the Rio Grande in New Mexico to support analysis of restoration options and river management strategies. The model set primarily was used to simulate exchanges between surface water and shallow groundwater within the flood plain of the Rio Grande. The Rio Grande and its associated drains and conveyance channels are the surfacewater features simulated by the model. The model uses boundary conditions set by model 10 and land use data from 2002 . The New Mexico Interstate Stream Commission uses the model to analyze river habitat.

\section{Model Surveys}

The accuracy of any model is, among other things, a function of the data that are input. Accurate and current input data will provide for more accurate and current model output values. The model surveys focus mainly on how the different models are handling input values and on what data they are relying.

\section{Surface-Water Models}

Many of the hydrologic elements surveyed in table 2 are shown as being included "implicitly" in a surface-water model. Implicit inclusion means that there is a place for that hydrologic element in the model, but instead of inputting data directly to represent that element, the element is either combined with other elements or is handled as a coefficient. Local flow calculations in URGWOM and URGSiM are examples of combining elements. Local flow is generally calculated as a portion of the difference between upstream main-stem flow and downstream main-stem flow for a particular reach, sometimes combined with irrigation diversions and return flows. In the case of the reach of the Rio Grande from Embudo to Otowi, even the largest tributary channels like the Santa Cruz River and the Pojoaque River, which flow much of the year, are included implicitly as a component of local flow. Although local flow is lumped for each reach, it does exhibit daily resolution in URGWOM because it is calculated for each day of the year, retroactively in that model. In URGSiM it is calibrated on a monthly basis. As shown in table 2, elements that are modeled implicitly as combined elements include tributary inflow, municipal and irrigation diversions, and return flows.

An example of using a coefficient would be to calculate a value as the difference between measured values and then to use the average of those differences over a time period in the model. Much of the flow loss for specific reaches above Cochiti Lake is addressed in both URGWOM and URGSiM through coefficients. Modeling elements implicitly through coefficients leads to an artificial smoothing in the temporal resolution of the model output. In other words, model outputs may agree with measured data on monthly, seasonal, or annual time scales, but the daily fluctuations of the hydrologic system will not be evident in the model output regardless of the model time step. As shown in table 2, elements that are modeled as coefficients include seepage gains and losses above Cochiti Lake. 
For predictive and planning models such as URGSiM and the Forecast, Planning, and Water Operations modules of URGWOM, computed values rather than actual data must be used for certain hydrologic elements. Instead of using the stream-gaging station data at Otowi, for example, both URGWOM and URGSiM compute the flow at Otowi. Depending on the assumptions used, error may be introduced during these computations. URGWOM and URGSiM generally incorporate gage data inputs where they are available at the model margins and use gage data within the model extent for calibration. The Accounting module of URGWOM uses all gage data available to back-calculate the current conditions on the river.

\section{Diversions and Return Flow}

For the Embudo to Otowi and Rio Chama reaches, URGWOM and URGSiM rely on similar assumptions for irrigable land and crop distribution to calculate irrigation diversions and return flows. URGWOM uses a variety of methods including calculations based on assumed irrigable acreages and assumed return flow, coefficients based on historical streamflow data (for the Rio Chama reach), and the lumping of diversions and return flows into the channel loss coefficient. In URGSiM, diversions are calculated on the basis of historical flow data during calibration and diversion rules during scenario runs. Crop consumption is calculated on the basis of climate data and assumptions about agricultural acreage and crop type. Return flows are then calculated as available water in the conveyance system less crop consumption, with some portion of those flows going back to the river and the rest continuing in the conveyance system to the next reach. Those ratios are based on model results during the historical period.

For the Otowi to Isleta reach, diversions are handled differently by each of the four surface-water models. In URGWOM, average monthly hydrographs for Rio Grande water diverted at irrigation canals are input, but San JuanChama water downstream from Cochiti Lake is not tracked. URGWOM handles municipal diversions by inputting data from the City of Albuquerque. By contrast, URGSiM continues to track Albuquerque's allocation of San Juan-Chama water downstream to Albuquerque. URGSiM calculates irrigation diversions and lumps the values. URGSiM uses per capita water-use data to calculate municipal diversions. In the Otowi to Isleta reach, DSS uses gaged values for irrigation diversions but does not address municipal diversions because it is simulating flow only in the irrigation canals and not in the Rio Grande main-stem channel. The FLO-2D model uses outflow hydrographs to simulate both irrigation and municipal diversions and does not differentiate between Rio Grande water and San Juan-Chama water. In both URGWOM and URGSiM, irrigation return flows in the Otowi to Isleta reach are calculated on the basis of diversion schedules, crop evapotranspiration, seepage, and drain information. Irrigation return flows are measured in DSS and are based on historical records in FLO-2D.

\section{Seepage}

Values for seepage gains to and losses from surface water generally are taken from a groundwater component of the models when available and otherwise modeled implicitly as a component of local flow, a component of irrigation return flow, or with a coefficient. There are no publicly available groundwater basin models for the Rio Chama or the Rio Grande in New Mexico north of the City of Española.

URGWOM uses a variety of methods to address surface-water interaction with groundwater. Where possible, surface-water/groundwater interactions were calculated as the difference between observed and routed flow for a calibration period (Embudo to Otowi reach and portions of the Rio Chama). In some reaches, surface-water gains were lumped with return flow into a monthly coefficient. For the San Juan-Chama water, a monthly coefficient for surface-water losses is used as defined in the Rio Grande Compact (Public Act No. 96, 76), and for the Otowi to Isleta reach a coarsely gridded component of the groundwater model is used. Tables of computed loss coefficients for each reach are available in the URGWOM physical model documentation (USACE and others, 2005a).

URGSiM models groundwater dynamics between the City of Española and Elephant Butte Reservoir by using a spatially aggregated representation of three groundwater basin models: the McAda and Barroll (2002) regional groundwater model, the Española Basin model by Frenzel (1995), and the Socorro Basin model by Shafike (2005). Upstream from the City of Española and in the Rio Chama reach, where there are no applicable groundwater basin models, URGSiM estimates a constant groundwater contribution to the river on the basis of winter gage analysis 1975-99 (Roach, 2007).

DSS does not consider seepage gains to surface water but instead models return flow from the riverside drains. DSS uses a global value of 1.5 percent loss per mile for all irrigation canals. The FLO-2D model does not account for seepage gains to or losses from surface water.

\section{Changes in Reservoir Storage}

Changes in storage for reservoirs included in the study area are modeled in similar ways by URGWOM and URGSiM but are not addressed by the DSS or FLO-2D models. Changes in reservoir storage are calculated as inflows less outflows in a given time step. Inflows include precipitation and river flows (Rio Grande water and San Juan-Chama water), and outflows include seepage, evaporation, and releases. Releases of Rio Grande water and San Juan-Chama water are controlled by a complex set of reservoir operation rules which guide all aspects of storage and release of water in the reservoirs. These reservoir operation rules, which are the most complex portions of both URGWOM and URGSiM, control release of Rio Grande water and San Juan-Chama water. El Vado Reservoir, Abiquiu Reservoir, and Cochiti Lake store Rio Grande water and San Juan-Chama water, but Heron Reservoir is authorized 
to store only San Juan-Chama water. Reduction in reservoir storage capacity due to sedimentation is also accounted for in Abiquiu Reservoir and Cochiti Lake by URGWOM.

The URGWOM Accounting module tracks four Rio Grande accounts for the El Vado Reservoir: Indian storage water (prior and paramount water), MRGCD drought water (based on a 2003 emergency drought water agreement), Rio Grande water, and supplemental water. According to the Accounting module documentation (USACE and others, 2005b), the amount of storage required for the six Middle Rio Grande Basin Pueblos is computed by the Bureau of Indian Affairs and the USBOR. Released prior and paramount water is simulated in the URGWOM Accounting module but is not tracked downstream from El Vado Reservoir.

\section{Evapotranspiration}

URGWOM and URGSiM calculate evaporation losses at reservoirs as the surface area of the reservoir times 70 percent of the panevaporation measured at the reservoir in a given time step. Both models then apportion losses between San Juan-Chama water and Rio Grande water according to accepted San Juan-Chama accounting rules. URGWOM handles evapotranspiration losses at locations other than reservoirs in the Rio Chama reach indirectly by assuming consumptive use of half of all agricultural diversions. In the Embudo to Otowi reach, URGWOM uses loss rates calculated for the reach between El Vado and Abiquiu Reservoirs on the Rio Chama. The URGSiM calculation for the Rio Chama reach and the Embudo to Otowi reach considers riparian, irrigated agricultural, and open river areas and the calculated potential loss rates from each. The FLO-2D model calculates monthly evaporation averages on the basis of free-surface evaporation for each hour of the day for the area north of Otowi but does not address evapotranspiration losses south of Otowi. Both URGWOM and URGSiM calculate daily evaporation for open water in Cochiti Lake and daily evapotranspiration values from riparian and agricultural areas in the reach between Otowi and Isleta. The DSS calculates evapotranspiration losses only for irrigated areas in this reach.

\section{Elements Not Addressed by Surface-Water Models}

None of the four surface-water models surveyed specifically address interaction between surface water and groundwater occurring at the wetlands downstream from Cochiti Lake. Both URGWOM and URGSiM do, however, model surface-water and groundwater interactions downstream from Cochiti Lake, an area that includes these wetlands. Other elements of interest that are not addressed by any of the surfacewater models include the hydrological aspects of Santa Cruz Reservoir and Nambe Lake, those of Horse Lake Creek above Heron Reservoir, or any aspect of water quality throughout the system.

\section{Groundwater Models}

\section{Model Characteristics}

Because only six of the groundwater models surveyed are identified as being currently in use (table 3 , models 4, 6, 9, 10,12 , and 13), this discussion will focus on those six models. URGSiM is not included explicitly here because its groundwater model is based on models 6 and 10. The purpose of models 4,6 , and 9 generally is to simulate the effect of groundwater withdrawals and drawdown. The purpose of models 10 and 12 is to improve understanding of the geohydrology of the areas modeled (Albuquerque Basin and the Los Alamos area, respectively). The purpose of model 13 contrasts with those of the other models in that model 13 is focused on simulating the shallow riparian groundwater environment. All six of these models are transient models, and all except model 13 have time periods beginning in the predevelopment period (predevelopment is considered to be prior to modern groundwater pumping). The ending time period for the six models is the early 21 st century. Model 13 has higher temporal and spatial resolution with the shortest time step ( 2 weeks to 5 months) and the smallest cell sizes $(0.02 \mathrm{mi}$ horizontal and $20 \mathrm{ft}$ vertical) of the six models. The more common time step for the groundwater models is months to years. Horizontal cell sizes for the other four models range from $0.1 \mathrm{mi}$ to $1 \mathrm{mi}$, and the vertical cell sizes range from tens to thousands of feet. Unlike the other five models, however, model 13 is not calibrated. Models 4, 6, and 10 are manually calibrated, and models 9 and 12 are automatically calibrated.

\section{Hydrologic Elements}

Because of their lineage, models 9 and 10 have the most similarities in terms of how various hydrologic elements of interest are addressed by the six currently used models. Wastewater return flow is addressed in models 4 and 6 as wastewater return from the Santa Fe wastewater treatment plants and in models 9 and 10 as septic return, but it is not addressed in models 12 and 13. Agricultural withdrawals are not addressed by any of the six models, but domestic well withdrawals (table 3 ) are addressed in models 4, 9, and 10. Irrigation return flow is addressed by only model 10. Evapotranspiration is addressed and provided as an output in models 9, 10, and 13 . With the exception of model 13, all of the models address groundwater withdrawals, usually based on NMOSE data. All five models provide groundwater levels as an output.

\section{Model Calibration}

All six currently used models employ water-level measurement data, but they differ in terms of model calibration and parameterization (table 3). Models 9 and 10 employ 
in situ seepage tests for model calibration or parameterization. Flow measurements at stream-gaging stations and differential streamflow seepage calculations are used in calibration or parameterization by all six models with the exception of model 13. Land use and (or) vegetative cover data are used in calibration or parameterization by models 9,10 , and 13 .

\section{Recharge}

The surveyed groundwater models simulate recharge to the aquifer in different ways. Recharge to an aquifer can be dependent on elevation and surface geology. It can occur from mountain-front seepage, tributary seepage, septic return flow, or irrigation seepage. Table 5 indicates how rates, locations, and types of recharge were determined and simulated for each model.

In terms of the six currently used models, recharge is modeled by all but model 13, although output values on recharge are provided by all models but model 12 (table 3 ). Factors used to assign recharge rates vary among models 4 , $6,9,10$, and 12 (table 5). The list of factors used to assign recharge rates in models 4 and 6 is the most comprehensive; it includes elevation, surface geology, mountain-front seepage, tributary seepage, and irrigation recharge. Models 9 and 10 both depend on irrigation recharge, septic return flow, tributary seepage, and mountain-front seepage to assign recharge rates. Additionally, model 9 uses surface geology in assigning recharge rates. Model 12 bases recharge rates on only elevation and tributary seepage.

\section{Surface-Water/Groundwater Interaction}

Surface-water/groundwater interactions simulated by groundwater models can provide valuable information to the surface-water models. The exchange of water between the Rio Grande and underlying shallow aquifers is quite large under some conditions. For example, comparisons between McAda and Barroll (2002) model results and stream-gaging station data indicate that, during periods of average October flow, nearly the entire flow of the Rio Grande can be expected to cycle once through the riverside drainage network as it travels downstream from Cochiti Dam to San Acacia. The groundwater models that include surface-water/groundwater interactions can provide large-scale estimates of flow between the Rio Grande and shallow aquifers, which can be an important component of the Rio Grande water budget as a whole. Table 6 shows how each groundwater model simulates surface-water/ groundwater interactions.

\section{Hydrologic Data Needs for Tracking Flow on the Rio Grande}

Several data gaps became apparent during the course of conducting the model surveys. Certain values in all models are estimated as coefficients or as calibration factors because the data do not exist or are insufficient. Deficient data or poorly constrained variables pertaining to surface-water models include data on seepage gains and losses in the Rio Grande, particularly upstream from Cochiti Lake and in the Rio Chama; irrigation return flows; seasonal and ephemeral tributary inflow; evapotranspiration rates; soil moisture values; high-flow, cross-section, and elevation surveys; and stream-gaging station data in sandy channels, which are of variable quality. Information on daily releases of San JuanChama water from Abiquiu Reservoir is available only when the URGWOM accounting model is run daily. A simulation of past prior and paramount releases made by using streamgaging station data from the period of the release to quantify problems that occurred during the release (such as insufficient volume of water or a delay in delivery) has not been completed. Deficient data or poorly constrained variables affecting groundwater models include groundwater conditions including groundwater levels and hydraulic conductivities between Cochiti Lake and Albuquerque, recharge, basin geologic structure, and current riparian area coverage.

Data on evapotranspiration, particularly from agricultural and riparian areas, are sparse. Groundwater and surface-water models both are sensitive to evapotranspiration values, but models evaluated in this study generally use assumed evapotranspiration values that do not reflect spatial or temporal variability and that have unknown associated errors. Both URGWOM and URGSiM calculate reference evapotranspiration based on climate data that are both spatially and temporally varying and use crop areas and crop types that are both spatially and temporally (by year) varying as well.

Statewide, there are little data on the contribution of flow from ephemeral channels to the main-stem rivers. This lack can be particularly problematic for tracking flow on a realtime or daily basis. Some ephemeral channels in the study area have drainage areas covering hundreds of square miles and can have flow rates of tens of thousands of cubic feet per second for large storm events.

Gaged data also are lacking for numerous perennial streams, such as Rio Ojo Caliente and Rio Nambe, near tributary confluences with the main-stem rivers. The lack of data regarding perennial tributary inflow on Rio Ojo Caliente and El Rito prohibits accurate calculations of Rio Chama channel conveyance from Abiquiu to the confluence with the Rio Grande. Channel losses estimated by models could be different from actual losses. Differences between channel loss estimates and actual losses may be compensated for in some models by a tributary inflow factor.

Hydrologic data are generally more complete for the reach of the Rio Grande between Cochiti Lake and Isleta Pueblo than they are for upstream from Cochiti Lake. The combination of continual urban development and large-scale agricultural use of the river valley downstream from Cochiti Lake has resulted in more interested stakeholders and has necessitated accurate monitoring of the water.

In all cases, the model results are only as good as the input data. The most recent hydrologic data are needed to 
accurately track prior and paramount releases. Ideally, these data would be continuously updated; however, a comprehensive source of such real-time data does not exist. Even daily data are sometimes difficult to obtain in a timely fashion for model operators (D.M. Roark, oral commun., May 2010) because the data come from multiple sources. Analysis of the 4 publicly available surface-water models and 13 publicly available groundwater models shows that, although elements from many models can be helpful in tracking flow in the Rio Grande, numerous data gaps and modeling needs indicate that accurate, consistent, and timely tracking of flow on the Rio Grande could be improved.

\section{Model Ability To Track Flow}

\section{Surface-Water Models}

Because it takes time for prior and paramount water to be released and to travel downstream to the pueblos, a model that is run in real time, or at least daily, could provide sufficient warning that streamflows are becoming low enough to require a release of prior and paramount water. Real-time or daily simulations would allow the Designated Engineer and the pueblos to monitor upstream indicators that prior and paramount water will be needed and thereby would help to prevent an unnecessary and perhaps costly delay in delivery of needed water. None of the surface-water models evaluated were designed to track flows on a real-time basis. URGWOM and DSS, for example, are capable of running on a daily time step; however, generally only the URGWOM accounting module is run daily, with a 1-day lag. URGSiM is designed to run on only a monthly time step. In some cases, the models are not run in real time because of the lack of real-time data to be used as inputs for the models.

Although none of the four surface-water models surveyed were designed specifically to quantify flow in the Rio Grande on a real-time basis, each can be helpful in accounting for different aspects of flow on the Rio Grande. URGSiM is a comprehensive model used to simulate flow in the Rio Grande and is used primarily as a rapid screening tool. URGSiM, when compared to URGWOM, includes less detail and has coarser spatial and temporal resolutions. It is, however, simpler to use, and the runtimes for simulations are much shorter than those in URGWOM. The DSS does not simulate flow in the Rio Grande, but it does include highly detailed information on the canal system south of Cochiti Lake that directly affects flow in the Rio Grande. The DSS model could be used to account for water delivery efficiency or to assess losses in the MRGCD canal system. Part of the strength of the DSS is that it includes a large amount of measured data for various processes and elements in the Middle Rio Grande Valley, including soil moisture, canal seepage, and evaporation. The measured data and canal system simulation provided by the DSS could be incorporated into a comprehensive water-resource model.
The FLO-2D model also is not applicable for tracking separate flow accounts. The applicability of the FLO-2D model regarding accounting flow in the Rio Grande is in routing of total flow or providing accurate traveltimes for flow in the Rio Grande for different flow conditions. Use of the flowrouting information gleaned from the FLO-2D model would be valuable in a detailed water-resource model.

In the model documentation for both the URGWOM and FLO-2D there is minimal discussion of uncertainty and errors associated with the model analysis, including sources of errors such as data input errors, simulation output errors, and model simplifications.

The FLO-2D model may provide the most realistic river routing since that is the purpose of the model. URGSiM and the DSS do not address routing, and URGWOM uses a simplified routing method.

The purpose of URGWOM - to simulate water storage and delivery operations in the Rio Grande-corresponds more closely than any of the other models evaluated to the mission of the Designated Engineer and the pueblos to track the available supply of flow to predict a need for prior and paramount water releases. Specifically, the strengths of URGWOM in relation to modeling flow are the detail and attention paid to the accounting of Rio Grande flow and San Juan-Chama flow. URGWOM relies on groundwater head values derived from the McAda and Barroll (2002) model, which means that URGWOM will be affected by any uncertainties that affect the McAda and Barroll (2002) model. Although URGWOM is designed to account for daily flows in the Rio Grande, only the Accounting module is run on a daily basis, although not consistently, mainly because daily data are not available in a timely manner from the various sources that supply it. There is a task in the Enhancement and Development section of the URGWOM 5-year plan schedule (http://www.spa.usace.army.mil/urgwom/ continuedevelopment.asp) for development of a real-time water operations model to be effective in 2015 .

\section{Groundwater Models}

Basic differences between the processes governing groundwater and surface-water flow lead to basic differences in the way groundwater and surface-water models are developed. Groundwater generally moves much more slowly than does surface water, and therefore, groundwater-model time steps are generally much larger than those used by surfacewater models. In addition, groundwater models generally have monthly or longer stress periods or time steps because stress data (recharge and pumpage) are generally only available for monthly or longer time periods. The groundwater models surveyed for this report cannot be expected to provide simulations of flow at time scales less than the simulated time step (1 month to 1 year in most cases).

Aquifers generally encompass areas much wider than do stream channels. Grid spacing in groundwater models is, therefore, often too large to accurately simulate local-scale 
processes active in surface-water channels. Although many groundwater models that include surface-water/groundwater interactions have smaller grid spacing near streams, the groundwater models surveyed in this report cannot provide accurate simulations of individual river drains or any feature that is smaller than the model cell size, for example, $0.6 \mathrm{mi}$ in the case of the McAda and Barroll (2002) model.

Of those of the currently used groundwater models, the purpose of model 13 (MacClune and others, 2006), to simulate the shallow riparian groundwater environment, is the most appropriate for examining local-scale surface-water/ groundwater interactions. The basin-scale models, however, are also important in understanding the large-scale water balances between the aquifers and the surface water. As evident in table 6, all of the groundwater models surveyed address surface-water/groundwater interactions at some level. Any surface-water model would benefit from incorporating data from the most accurate and current groundwater model available. In the case of the Upper and Middle Rio Grande Valley, models 6 (Frenzel, 1995), 10 (McAda and Barroll, 2002), and 12 (Keating and others, 2005) are the most accurate and current groundwater models available.

\section{Summary}

The six Middle Rio Grande Basin Pueblos have prior and paramount rights to deliveries of water from the Rio Grande for their use. When the pueblos or the Bureau of Indian Affairs Designated Engineer identifies a need for additional flow on the Rio Grande, the Designated Engineer is tasked to decide when and how much prior and paramount water to release from storage at El Vado Reservoir to meet the needs of the pueblos. Over the last three decades, numerous models have been developed by Federal, State, and local agencies in New Mexico to simulate, understand, and (or) manage flows in the Middle Rio Grande upstream from Elephant Butte Reservoir. Analysis of 4 publicly available surface-water models and 13 publicly available groundwater models shows that, although elements from many models can be helpful in tracking flow in the Rio Grande, numerous data gaps and modeling needs indicate that accurate, consistent, and timely tracking of flow on the Rio Grande could be improved.

Deficient or poorly constrained hydrologic variables are sources of uncertainty that can be reduced with the acquisition of more refined data. Data gaps need to be filled to allow hydrologic models to be run on a real-time basis and thus ensure predictable water deliveries to meet needs for irrigation, domestic, stock, and other water uses. Deficient data or poorly constrained variables pertaining to surface-water models include data on seepage gains and losses in the Rio Grande, particularly upstream from Cochiti Lake and in the Rio Chama; irrigation return flows; seasonal and ephemeral tributary inflow; evapotranspiration rates; soil-moisture values; high-flow, cross-section, and elevation surveys on the Rio Grande; and stream-gaging station data in sandy channels, which are of variable quality. Information on daily releases of San Juan-Chama water from Abiquiu Reservoir is available in only a provisional form from the Accounting module of the Upper Rio Grande Water Operations Model (URGWOM) model with a 1-day lag. Deficient data or poorly confined hydrologic variables affecting groundwater models include groundwater conditions including groundwater levels and hydraulic conductivities between Cochiti Lake and Albuquerque, recharge, basin geologic structure, and current riparian area coverage. Data on evapotranspiration, particularly from agricultural and riparian areas, are sparse.

In all cases, the model results are only as good as the input data. The most recent hydrologic data are needed to accurately track prior and paramount releases. Ideally, these data would be continuously updated; however, a comprehensive source of such real-time data does not exist. Daily data are even sometimes difficult to obtain in a timely fashion for model operators because the data come from multiple sources.

Each surface-water model produces results that could be helpful in quantifying the flow of the Rio Grande, specifically by helping to track water as it moves down the channel of the Rio Grande and by improving the understanding of river hydraulics for the specified reaches. The ability of each surface-water model to track flow on the Rio Grande varies according to the purpose for which each model was designed. The purpose of URGWOM - to simulate water storage and delivery operations in the Rio Grande-is more applicable to tracking flow on the Rio Grande than are any of the other surface-water models surveyed. Specifically, the strengths of URGWOM in relation to modeling flow are the details and attention given to the accounting of Rio Grande flow and San Juan-Chama flow at a daily time step.

The most significant difficulty in using any of the surveyed surface-water models for the purpose of predicting the need for requested water releases is that none of the surface-water models surveyed consider water accounting on a real-time basis. The Accounting module of URGWOM is capable of tracking flows on a daily basis but does so only with a 1-day lag. In most cases, it is the lack of a dependable database or source of real-time data that prohibits the models' abilities to run in real time.

Groundwater models that provide detailed simulations of shallow groundwater flow in the vicinity of the Rio Grande can provide large-scale estimates of flow between the Rio Grande and shallow aquifers, which can be an important component of the Rio Grande water budget as a whole. The groundwater models surveyed for this report cannot, however, be expected to provide simulations of flow at time scales of less than the simulated time step (1 month to 1 year in most cases). Although many groundwater models that include surface-water/groundwater interactions have smaller grid spacing near streams, the groundwater models surveyed in this report cannot provide accurate simulations of individual river channels, drains, or any feature smaller than the model cell size, for example, 0.6 miles in the case of model 10. Of 
those of the currently used groundwater models, the purpose of model 13- to simulate the shallow riparian groundwater environment-is the most appropriate for examining localscale surface-water/groundwater interactions. The basinscale models, however, are also important in understanding the large-scale water balances between the aquifers and the surface water. In the case of the Upper and Middle Rio Grande Valley, models 6, 10, and 12 are the most accurate and current groundwater models available.

\section{References Cited}

Barroll, P., 2001, Documentation of the administrative groundwater model for the Middle Rio Grande Basin: Office of the State Engineer, Technical Services Unit, Hydrology Bureau Report 99-3.

Chestnut, Peter, 1999, A Pueblo Perspective on the Rio Grande Compact, WRRI Report No. 312, The Rio Grande Compact-It's the Law!: Water Resources Research Institute, 44th Annual New Mexico Water Conference Proceedings.

Frenzel, P.F., 1995, Geohydrology and simulation of groundwater flow near Los Alamos, north-central New Mexico: U.S. Geological Survey Water-Resources Investigations Report 95-4091, 92 p.

Harbaugh, A.W., Banta, E.R., Hill, M.C., and McDonald, M.G., 2000, MODFLOW-2000, the U.S. Geological Survey modular ground-water model-User guide to modularization concepts and the ground-water flow process: U.S. Geological Survey Open-File Report 00-92, 121 p.

Hearne, G.A., 1985a, Mathematical model of the Tesuque aquifer system near Pojoaque, New Mexico: U.S. Geological Survey Water-Supply Paper 2205, 75 p.

Hearne, G.A., 1985b, Simulation of an aquifer test on the Tesuque Pueblo Grant, New Mexico: U.S. Geological Survey Water-Supply Paper 2206, 24 p.

Keating, E.H., Robinson, B.A., and Vesselinov, V.V., 2005, Development and application of numerical models to estimate fluxes through the regional aquifer beneath the Pajarito Plateau: Vadose Zone Journal, v. 4, p. 653-671.

Kernodle, J.M., 1992, Summary of U.S. Geological Survey ground-water-flow models of basin-fill aquifers in the southwestern alluvial basins region, Colorado, New Mexico, and Texas: U.S. Geological Survey Open-File Report 90-361.

Kernodle, J.M., 1998, Simulation of ground-water flow in the Albuquerque Basin, central NM, 1901-1995, with projections to 2020 (supplement two to U.S. Geological Survey Water-Resources Investigations Report 94-4251): U.S. Geological Survey Open-File Report 96-209, 54 p.
Kernodle, J.M., McAda, D.P., and Thorn, C.R., 1995, Simulation of ground-water flow in the Albuquerque Basin, central NM, 1901-1994, with projections to 2020: U.S. Geological Survey Water-Resources Investigations Report 94-4251.

Kernodle, J.M., Miller, R.S., Scott, W.B., 1987, Threedimensional model simulation of transient ground-water flow in the Albuquerque-Belen Basin, New Mexico: U.S. Geological Survey Water-Resources Investigations Report 86-4194.

Kernodle, J.M., and Scott, W.B., 1986, Three-dimensional model simulation of steady-state ground-water flows in the Albuquerque-Belen Basin, New Mexico: U.S. Geological Survey Water-Resources Investigations Report 84-4353.

MacClune, K.L., Barth, G., Shafike, N., and Hathaway, D., 2006, High-resolution groundwater models for the assessment of riparian restoration options and river conveyance efficiency, in Poeter, E., Hill, M., and Zheng, C., eds., 2006, MODFLOW and More-Managing Ground-Water Systems: Conference Proceedings, p. 159-163.

Mann, Joshua, 2007, A reservoir runs through it - A legislative and administrative history of the six pueblo's right to store "prior and paramount" water at El Vado: Natural Resources Journal, v. 47, no. 3, p. 733-768.

McAda, D.P., 1990, Simulation of the effects of ground-water withdrawal from a well field adjacent to the Rio Grande, Santa Fe County, New Mexico: U.S. Geological Survey Water-Resources Investigations Report 89-4184.

McAda, D.P., and Barroll, P., 2002, Simulation of groundwater flow in the Middle Rio Grande Basin between Cochiti and San Acacia, New Mexico: U.S. Geological Survey Water-Resources Investigations Report 02-4200.

McAda, D.P., and Wasiolek, M., 1988, Simulation of the regional geohydrology of the Tesuque aquifer system near Santa Fe, New Mexico: U.S. Geological Survey WaterResources Investigations Report 87-4056.

Oad, Ramchand, Kristoph-Dietrick, K., Manana, N., Garcia, L., Patterson, D., and Shafike, N., 2009, Implementation of efficient irrigation water delivery in the Middle Rio Grande utilizing a decision support system: New Mexico Interstate Stream Commission, ESA FY 2008 project report, 108 p., accessed May, 26, 2010, at http://mrgcd.com/DSS.aspx.

PRISM Climate Group, 2009, Prism products matrix, U.S. precipitation, 1971-2000, 30-arcsec (800m) normals: Oregon State University, accessed November 2009 at http://prism.oregonstate.edu/products/matrix.phtml.

Reddi, L.N., Lee, I.M., and Wu, T.H., 1990, A comparison of models predicting groundwater levels on hillside slopes: Water Resources Bulletin, American Water Resources Association, v. 26, no. 4. 
Reeder, H.O., Bjorklund, L.J., and Dinwiddie, G.A., 1967, Quantitative analysis of water resources in the Albuquerque area, New Mexico-Computed effects on the Rio Grande of pumpage of ground water, 1960-2000: New Mexico State Engineer Technical Report 33, 34 p.

Reese, April, 2009, Aquifer recharge projects catching on in water-strapped cities: Washington, D.C., E\&E Publishing, LLC, Land Letter, accessed April 26, 2011, at http://www. eenews.net/public/Landletter/2009/04/02/12.

Riada Engineering, Inc., 2008, FLO-2D flood routing model development Middle Rio Grande Cochiti Dam to Elephant Butte Reservoir 250-foot grid system: Prepared for the U.S. Army Corps of Engineers Albuquerque District.

Roach, J.D., 2007, Integrated surface-water groundwater modeling in the Upper Rio Grande in support of scenario analysis: University of Arizona, Department of Hydrology and Water Resources, Ph.D. dissertation, accessed March 11, 2011, at http://etd.library.arizona.edu/etd/ GetFileServlet?file=file:///data1/pdf/etd/azu_etd_2030_1_m. pdf\&type $=$ application/pdf.

Roach, Jesse, and Tidwell, V., 2009, A compartmental-spatial system dynamics approach to ground water modeling: Ground Water, v. 47, no. 5, p. 686-698.

Sanchez, V., 2007, Carryover storage of Indian prior and paramount water in El Vado: Natural Resources Journal, v. 47, p. $697-732$.

Sanford, W.E., Plummer, L.N., McAda, D.P., Bexfield, L.M., and Anderholm, S.K., 2003, Use of environmental tracers to estimate parameters for a predevelopment ground-waterflow model of the Middle Rio Grande Basin, NM: U.S. Geological Survey Water-Resources Investigations Report 03-4286.

Shafike, N.G., 2005, Linked surface water and groundwater model for Socorro and San Marcial Basins between San Acacia and Elephant Butte Reservoir, appendix J of Upper Rio Grande Water Operations Review DEIS, p. J-59 to J-94, accessed March, 11, 2010 at http://www.spa.usace.army. mil/urgwops/deis/URGWOPS\%20DEIS\%20Volume\%202/ URGWOPS\%20Appendix\%20J.pdf.
Tetra Tech, Inc., 2004, Development of the Middle Rio Grande FLO-2D flood routing model, Cochiti Dam to Elephant Butte Reservoir: Prepared for the Bosque Initiative Group, U.S. Fish and Wildlife Service and the U.S. Army Corps of Engineers, Albuquerque, New Mexico accessed January 2010 at http://www.fws.gov/southwest/bhg/PDFs/ FLO2D04.pdf.

Tiedeman, C.R., Kernodle, J.M., and McAda, D.P., 1998, Application of nonlinear-regression methods to a groundwater flow model of the Albuquerque Basin, New Mexico: U.S. Geological Survey Water-Resources Investigations Report 98-4172.

U.S. Army Corps of Engineers, U.S. Geological Survey, U.S. Bureau of Reclamation, U.S. Fish and Wildlife Service, U.S. Bureau of Indian Affairs, and International Boundary and Water Commission, 2002, Upper Rio Grande water operations model, physical model appendix (PHYGRAPH): accessed March 29, 2010, at http://www.spa.usace.army.mil/ urgwom/documentation/PHYGRAPH\%20(December,\%20 2002).pdf.

U.S. Army Corps of Engineers, U.S. Geological Survey, U.S. Bureau of Reclamation, U.S. Fish and Wildlife Service, U.S. Bureau of Indian Affairs, and International Boundary and Water Commission, 2005a, Upper Rio Grande water operations model, physical model documentation-Third technical review committee draft: accessed March 29, 2010, at http://www.spa.usace.army.mil/urgwom/documentation/ Physical\%20Model\%20Documentation\%20(June,\%20 2005)\%20(PHYMOD).pdf.

U.S. Army Corps of Engineers, U.S. Geological Survey, U.S. Bureau of Reclamation, U.S. Fish and Wildlife Service, U.S. Bureau of Indian Affairs, and International Boundary and Water Commission, 2005b, Upper Rio Grande Water Operations Model, Physical Accounting Model Documentation: accessed March 29, 2010, at http://www.spa.usace.army.mil/urgwom/documentation/ Physical\%20Accounting\%20Model\%20(June,2005)\%20 (PHYACCT).pdf.

Winter, T.C., Harvey, J.W., Franke, O.L., and Alley, W.M., 1998, Ground water and surface water-A single resource: U.S. Geological Survey Circular 1139, 79 p. 
Table 1. General characteristics of the surveyed surface-water models.

[SNL, Sandia National Laboratory; USACE, U.S. Army Corps of Engineers; USGS, U.S. Geological Survey; MRGCD, Middle Rio Grande Conservancy District; N/A, not applicable]

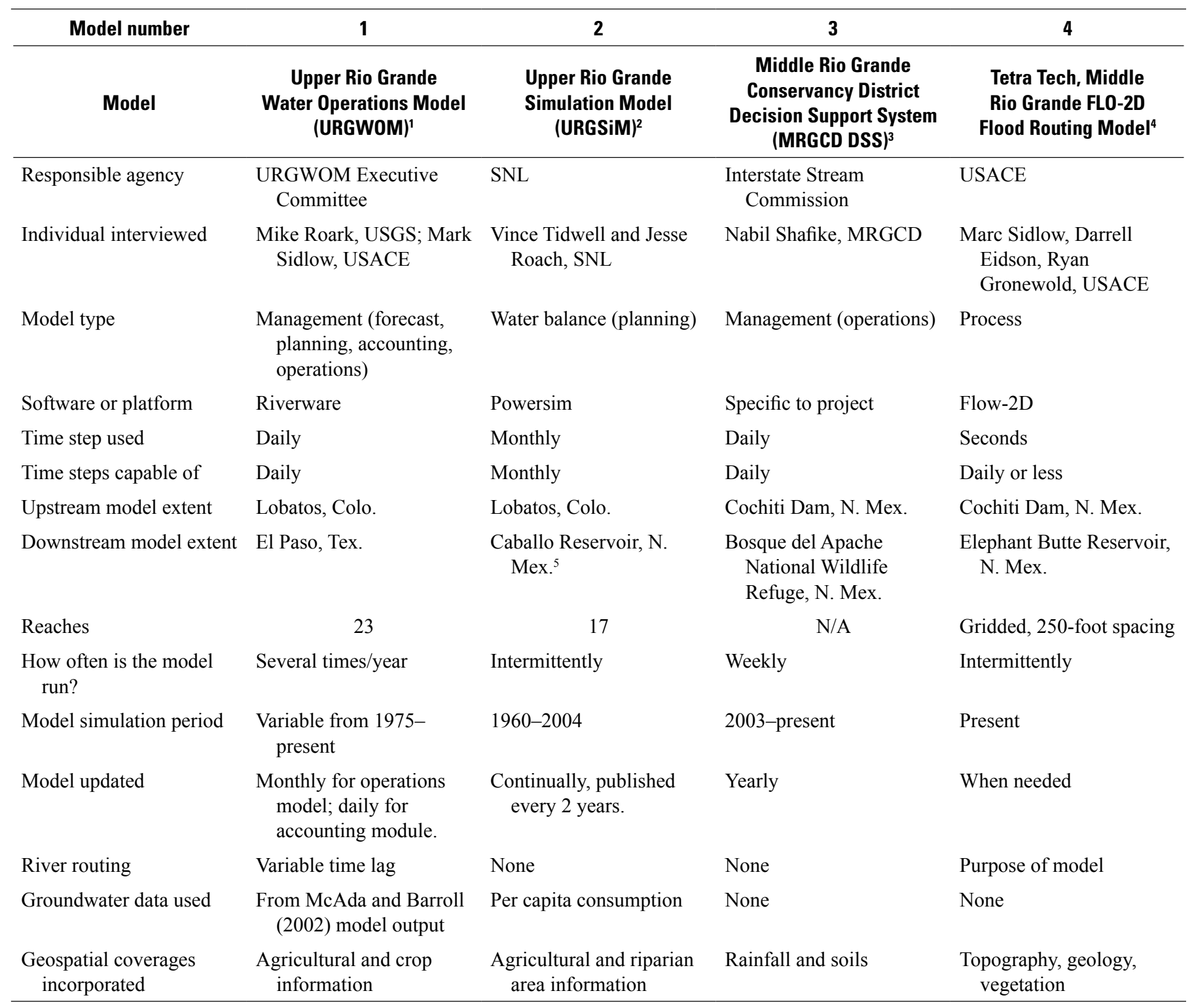

${ }^{1}$ U.S. Army Corps of Engineers and others, 2005a and 2005b.

${ }^{2}$ Roach, 2007.

${ }^{3} \mathrm{Oad}$ and others, 2009.

${ }^{4}$ Tetra Tech, Inc., 2004, and Riada Engineering, Inc., 2008.

${ }^{5}$ Caballo Reservoir is approximately 25 river miles downstream of Elephant Butte Reservoir. 
Table 2. Summary of treatments of hydrologic elements by the surveyed surface-water models:

[N/A, not applicable; EPA, Environmental Protection Agency; \%, percent; cfs, cubic feet per second; SJC, San Juan-Chama; DD, diversion dam; AMAFCA, Albuquerque Metropolitan Arroyo Flood Control Authority]

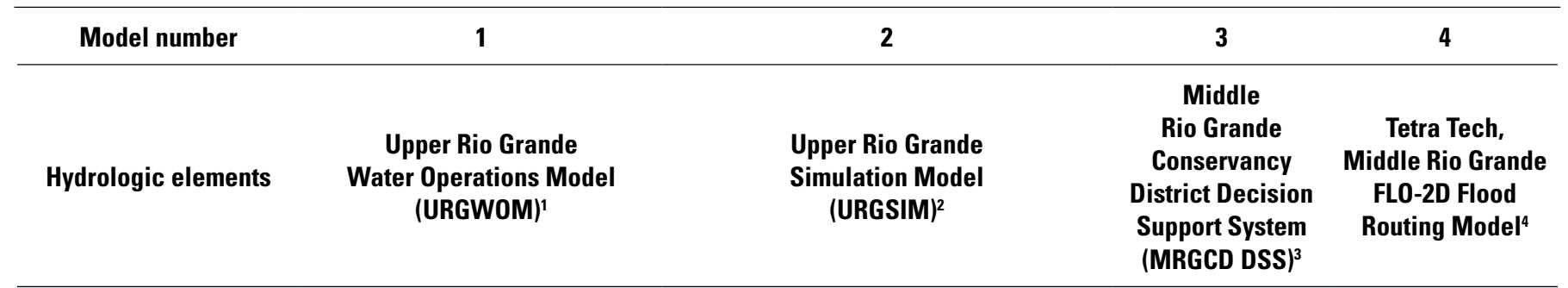

Rio Grande, Embudo to Otowi Bridge reach

\begin{tabular}{|c|c|c|c|c|}
\hline \multicolumn{5}{|l|}{ Inflow } \\
\hline $\begin{array}{l}\text { Rio Grande at } \\
\text { Embudo }\end{array}$ & $\begin{array}{l}\text { Computed from upstream } \\
\text { inflows. }\end{array}$ & Computed from upstream inflows. & N/A & N/A \\
\hline Santa Cruz River & $\begin{array}{l}\text { Included implicitly }{ }^{5} \text { as compo- } \\
\text { nent of local flow. }\end{array}$ & $\begin{array}{l}\text { Included implicitly as component of } \\
\text { local flow. }\end{array}$ & N/A & N/A \\
\hline Pojoaque River & $\begin{array}{l}\text { Included implicitly as compo- } \\
\text { nent of local flow }\end{array}$ & $\begin{array}{l}\text { Included implicitly as component of } \\
\text { local flow. }\end{array}$ & N/A & N/A \\
\hline $\begin{array}{l}\text { Ephemeral channel } \\
\text { storm-water flow }\end{array}$ & $\begin{array}{l}\text { Included implicitly as compo- } \\
\text { nent of local flow. }\end{array}$ & $\begin{array}{l}\text { Included implicitly as component of } \\
\text { local flow, calibrated to historical } \\
\text { rainfall data. }\end{array}$ & N/A & N/A \\
\hline $\begin{array}{l}\text { City of Española } \\
\text { effluent return }\end{array}$ & Input EPA time series data. & $\begin{array}{l}\text { Calculated on the basis of population } \\
\text { and water use characteristics. }\end{array}$ & N/A & N/A \\
\hline $\begin{array}{l}\text { Irrigation return } \\
\text { flows }\end{array}$ & $\begin{array}{l}\text { Model assumes approximately } \\
5,000 \text { acres of irrigable } \\
\text { land and assumes } 50 \% \\
\text { return flow. }\end{array}$ & $\begin{array}{l}\text { Model assumes approximately } \\
\text { 5,000 acres of irrigable land, as- } \\
\text { sumes crop distribution is same } \\
\text { as Rio Chama reach, and assumes } \\
\text { double potential crop consumption } \\
\text { diverted and half of that returns. }\end{array}$ & N/A & N/A \\
\hline Seepage gains & $\begin{array}{l}\text { Simulated by using the River- } \\
\text { ware "Seasonal Gain Loss } \\
\text { Flow Table" and part of the } \\
\text { local inflow hydrograph. }\end{array}$ & $\begin{array}{l}\text { Above Española, it is a component } \\
\text { ( } 71 \mathrm{cfs} \text { ) of the local inflow; down- } \\
\text { stream of Espanola it is taken from } \\
\text { the Espanola basin groundwater } \\
\text { model in URGSiM. }\end{array}$ & N/A & N/A \\
\hline \multicolumn{5}{|l|}{ Outflow } \\
\hline $\begin{array}{l}\text { Rio Grande at Otowi } \\
\text { Bridge }\end{array}$ & $\begin{array}{l}\text { Computed from upstream } \\
\text { inflows in Water Operations } \\
\text { Module and input directly } \\
\text { into the Accounting module } \\
\text { to compute local inflows. }\end{array}$ & Computed from upstream inflows. & N/A & $\begin{array}{l}\text { Model simulates a } \\
\text { variety of flows } \\
\text { at Otowi. }\end{array}$ \\
\hline $\begin{array}{l}\text { Rio Grande water ir- } \\
\text { rigation diversions; } \\
\text { Los Chicos, La } \\
\text { Canova, El Medio, } \\
\text { Garcia, Lyden, } \\
\text { Rinconada Isla, } \\
\text { Alcalde, El Guique, } \\
\text { San Juan }\end{array}$ & $\begin{array}{l}\text { Included implicitly within in- } \\
\text { put time series "return flow } \\
\text { amount" derived during } \\
\text { calibration. }\end{array}$ & $\begin{array}{l}\text { Model assumes approximately } 5,000 \\
\text { acres of irrigable land, assumes crop } \\
\text { distribution is same as Rio Chama } \\
\text { reach, and assumes double potential } \\
\text { crop consumption diverted. }\end{array}$ & N/A & \\
\hline
\end{tabular}


Table 2. Summary of treatments of hydrologic elements by the surveyed surface-water models. - Continued

[N/A, not applicable; EPA, Environmental Protection Agency; \%, percent; cfs, cubic feet per second; SJC, San Juan-Chama; DD, diversion dam; AMAFCA, Albuquerque Metropolitan Arroyo Flood Control Authority]

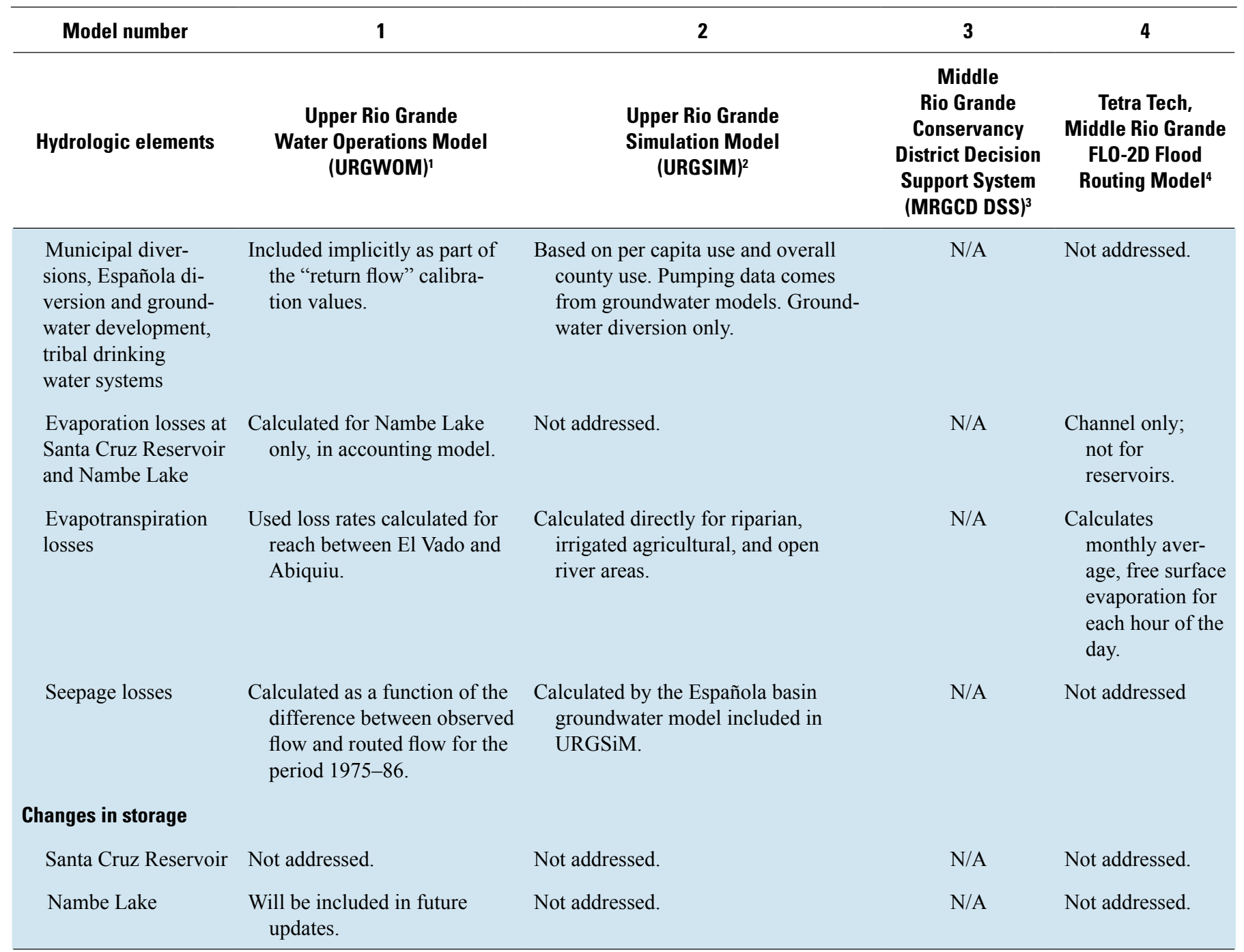

Rio Chama reach

Inflow

Horse Lake Creek Not addressed. above Heron

Reservoir

Willow Creek above Heron Reservoir

Rio Chama near La Puente

Rio Ojo Caliente

Ephemeral channel storm-water flow
Calculated as the difference between the Heron Reservoir outlet and the gage above Heron Reservoir.

Included implicitly as component of local flow.

Included implicitly as compo- Input gage data. nent of local flow.

Included implicitly as component of local flow.

Reservoir.

Input gage data. local flow.
Part of native contributions to Heron

N/A

N/A

Calclulated as tunnel flows less losses,

N/A

N/A plus native contributions to Heron.

N/A

N/A

N/A

N/A

Included implicitly as component of

N/A

N/A 
Table 2. Summary of treatments of hydrologic elements by the surveyed surface-water models.-Continued

[N/A, not applicable; EPA, Environmental Protection Agency; \%, percent; cfs, cubic feet per second; SJC, San Juan-Chama; DD, diversion dam; AMAFCA, Albuquerque Metropolitan Arroyo Flood Control Authority]

\begin{tabular}{|c|c|c|c|c|}
\hline Model number & 1 & 2 & 3 & 4 \\
\hline
\end{tabular}

Intermountain transfer from Azotea

Tunnel

Gaged at the tributary tunnels

Irrigation return flows

Seepage gains

\section{Outflow}

Rio Chama at Chamita gage

Chama water irrigation diversions

Evaporation losses from Rio Chama reservoirs

Evapotranspiration losses

Seepage losses

Distinction between stored and nonstored water in Rio Chama
Calculated.

Included implicitly, lumped with the irrigation return flow coefficient.

Total is $70 \%$ of panevaporation multiplied by surface area at gaged reservoir elevation. SJC portion is based on accounting calculations. calculations.

For SJC water, uses monthly loss coefficient defined in the Rio Grande Compact, otherwise calculated the same as for Embudo reach for Rio Grande Water.

Calculates total Rio Grande and SJC project water storage.
Combined with seepage loss to Azotea Tunnel and caluclated for Azotea Tunnel.

Input gage data (from Azotea Tunnel).

N/A

N/A (Recent versions of URGSiM calculate Azotea flows based on flows in San Juan tributaries that are diverted and diversion rules).

Model uses Chama adjudication

N/A

N/A agricultural areas and crop mix and calculates crop demand. Returns of the channel loss coefficient. Calculated by using 1971-85 historical streamflow data and assuming 50\% return flow.

diversions in excess of crop demand.

Uses a constant groundwater inflow

N/A

N/A in with the irrigation return flow coefficient.
Calculated.

N/A

N/A

Model uses Chama adjudication

N/A

N/A

agricultural areas and crop mix and calculates crop demand. Diversions are historical values during calibration and double crop demand in scenario period.

Total is $70 \%$ of panevaporation multiplied by surface area at gaged reservoir elevation. SJC portion is based on accounting calculations.

Calculated.

N/A

N/A

None; all reaches modeled as con-

N/A

N/A stant gaining based on winter gage analysis.

Calculates total Rio Grande and SJC

N/A

N/A 
Table 2. Summary of treatments of hydrologic elements by the surveyed surface-water models. - Continued

[N/A, not applicable; EPA, Environmental Protection Agency; \%, percent; cfs, cubic feet per second; SJC, San Juan-Chama; DD, diversion dam; AMAFCA, Albuquerque Metropolitan Arroyo Flood Control Authority]

\begin{tabular}{|c|c|c|c|c|}
\hline Model number & 1 & 2 & 3 & 4 \\
\hline
\end{tabular}

\section{Changes in storage}

\begin{tabular}{ll}
\hline Rio Grande water & \\
\hline El Vado Reservoir & $\begin{array}{l}\text { Calculated as the difference } \\
\text { between Rio Grande inflow } \\
\text { and outflow minus the SJC } \\
\text { water. }\end{array}$
\end{tabular}

Abiquiu Reservoir

Calculated similar to El Vado except sediment displacement calculations are added.

\section{Calculated similar to URGWOM by using reservoir release rules in com- bination with a mass balance to track inflows and outflows while account- ing for seepage, ice cover, and other variables.}

Calculated as with El Vado Reservoir.
N/A

N/A

\begin{tabular}{|c|c|c|c|c|}
\hline \multicolumn{5}{|l|}{ SJC water } \\
\hline $\begin{array}{l}\text { El Vado Reservoir } \\
\text { (mainly stores native } \\
\text { runoff but can store } \\
\text { SJC water) }\end{array}$ & $\begin{array}{l}\text { Calculated in accounting, wa- } \\
\text { ter operations, and planning } \\
\text { models. }\end{array}$ & $\begin{array}{l}\text { Calculated similar to URGWOM by } \\
\text { using reservoir release rules in com- } \\
\text { bination with a mass balance to track } \\
\text { inflows and outflows while account- } \\
\text { ing for seepage, ice cover, and other } \\
\text { variables. }\end{array}$ & $\mathrm{N} / \mathrm{A}$ & N/A \\
\hline $\begin{array}{l}\text { Abiquiu Reservoir } \\
\text { (mainly flood con- } \\
\text { trol and some SJC } \\
\text { storage) }\end{array}$ & $\begin{array}{l}\text { Calculated in accounting, wa- } \\
\text { ter operations, and planning } \\
\text { models. }\end{array}$ & Calculated as with El Vado Reservoir. & $\mathrm{N} / \mathrm{A}$ & N/A \\
\hline $\begin{array}{l}\text { Heron Reservoir } \\
\text { (SJC water storage) }\end{array}$ & $\begin{array}{l}\text { Calculated in accounting, wa- } \\
\text { ter operations, and planning } \\
\text { models. }\end{array}$ & Calculated as with El Vado Reservoir. & $\mathrm{N} / \mathrm{A}$ & N/A \\
\hline
\end{tabular}

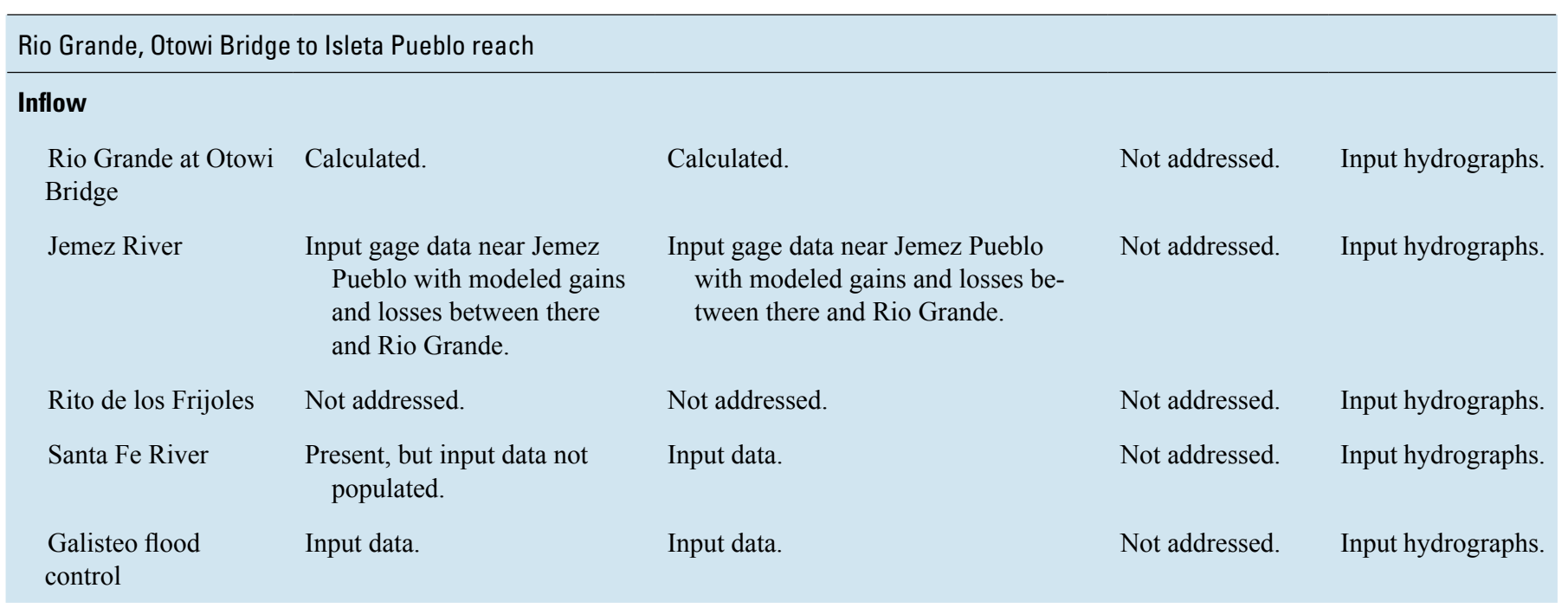


Table 2. Summary of treatments of hydrologic elements by the surveyed surface-water models. - Continued

[N/A, not applicable; EPA, Environmental Protection Agency; \%, percent; cfs, cubic feet per second; SJC, San Juan-Chama; DD, diversion dam; AMAFCA, Albuquerque Metropolitan Arroyo Flood Control Authority]

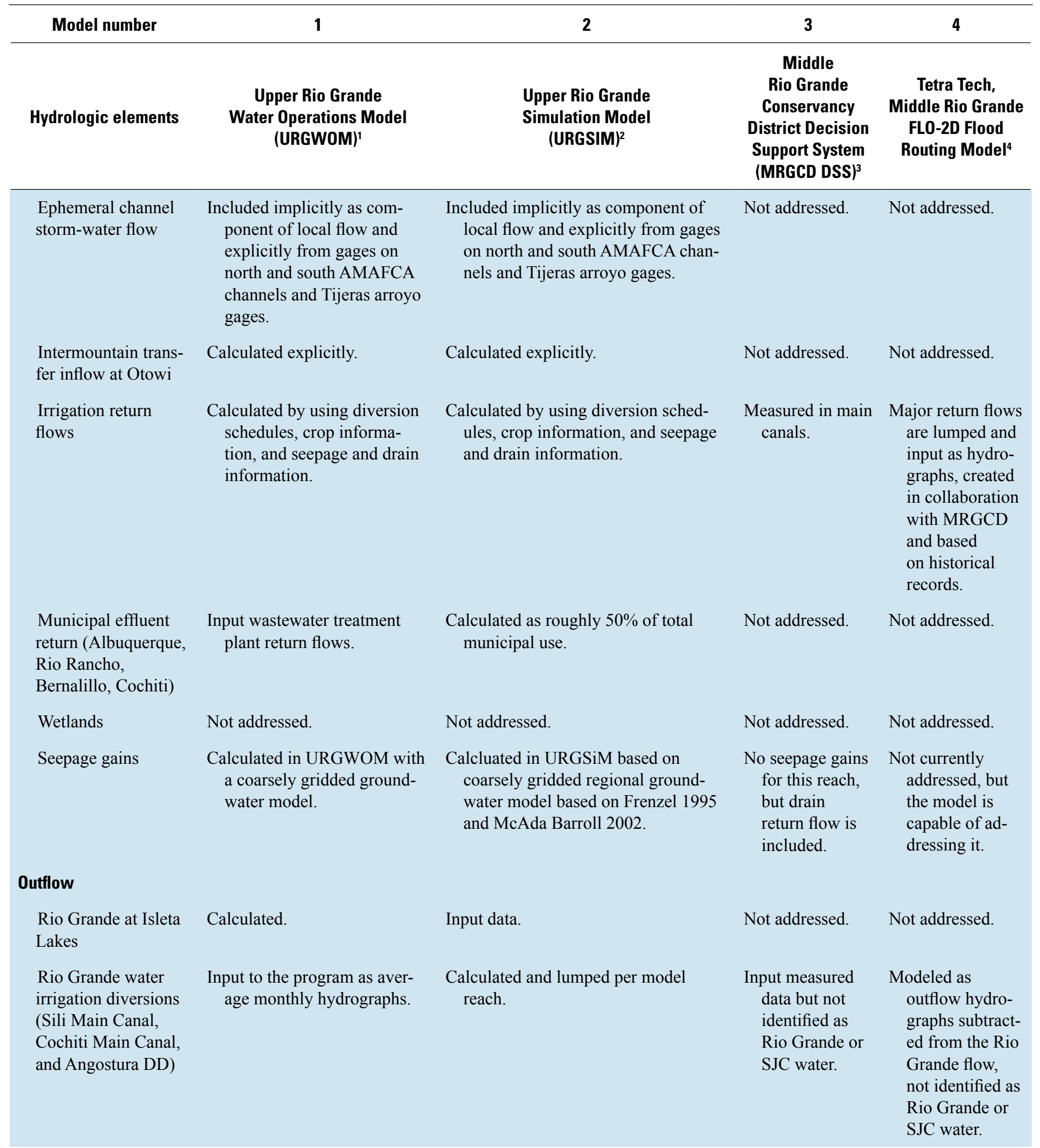


Table 2. Summary of treatments of hydrologic elements by the surveyed surface-water models. - Continued

[N/A, not applicable; EPA, Environmental Protection Agency; \%, percent; cfs, cubic feet per second; SJC, San Juan-Chama; DD, diversion dam; AMAFCA, Albuquerque Metropolitan Arroyo Flood Control Authority]

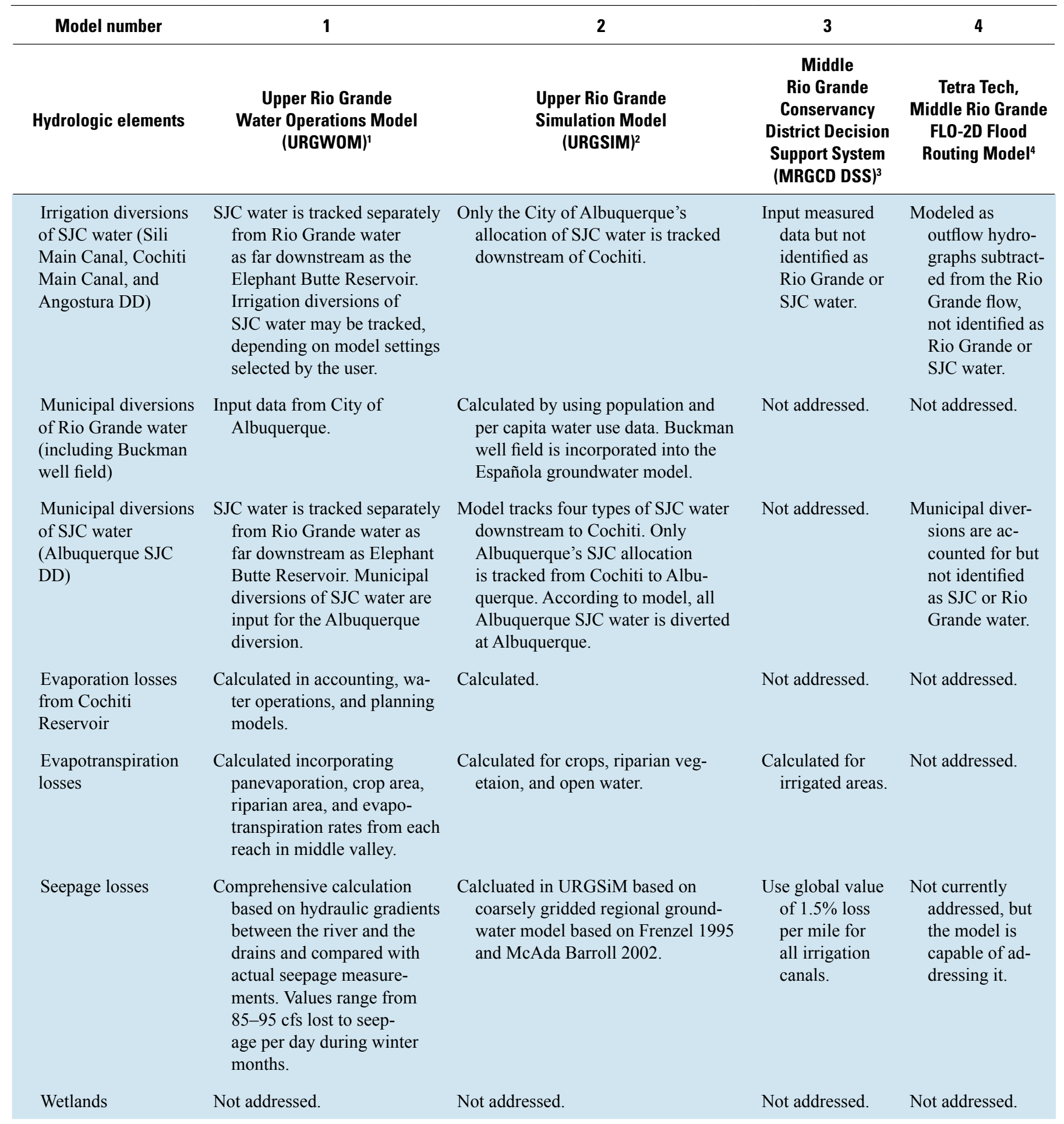


Table 2. Summary of treatments of hydrologic elements by the surveyed surface-water models. - Continued

[N/A, not applicable; EPA, Environmental Protection Agency; \%, percent; cfs, cubic feet per second; SJC, San Juan-Chama; DD, diversion dam; AMAFCA, Albuquerque Metropolitan Arroyo Flood Control Authority]

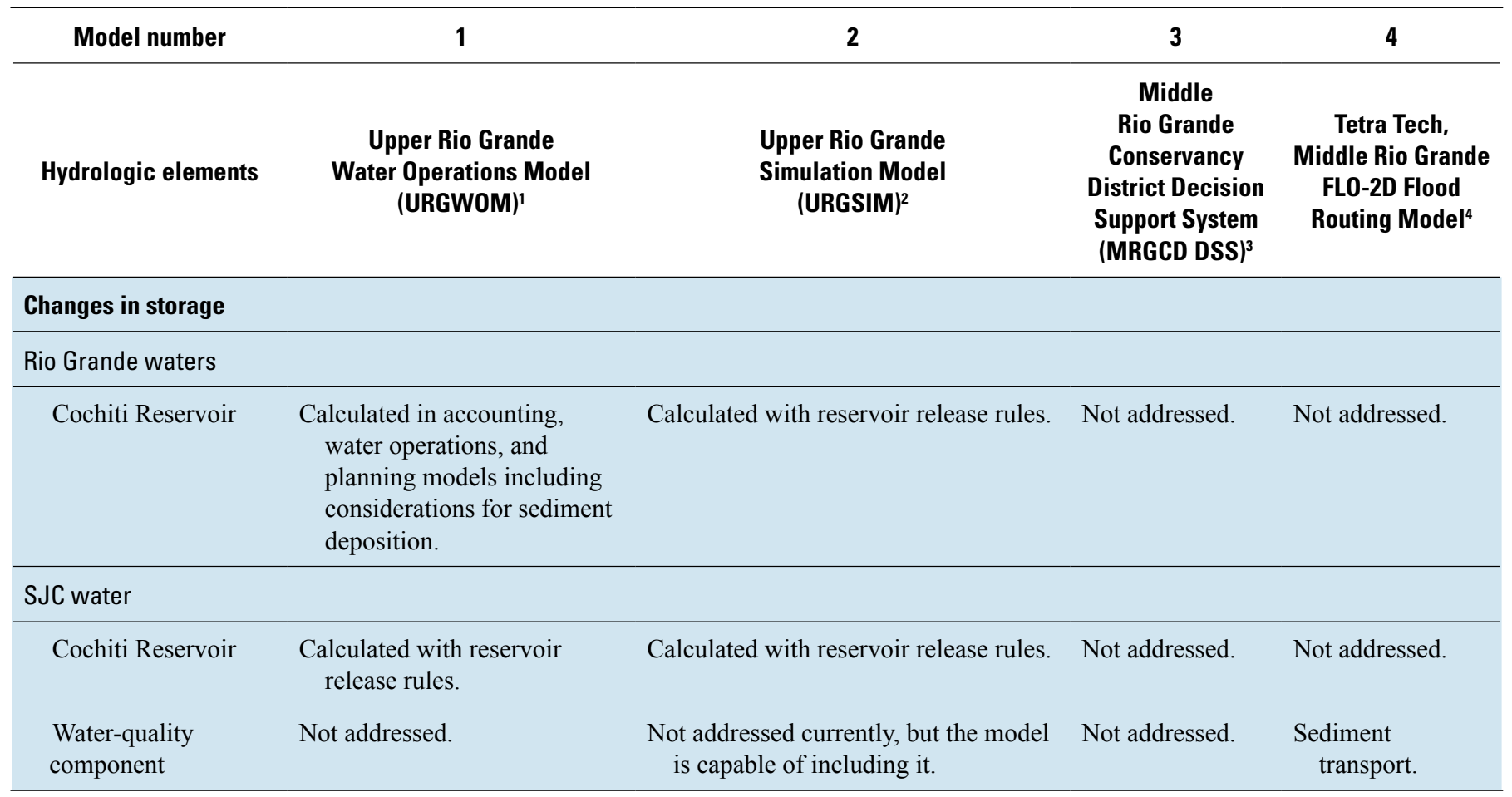

${ }^{1}$ U.S. Army Corps of Engineers and others, 2005a and 2005b.

${ }^{2}$ Roach, 2007.

${ }^{3}$ Oad and others, 2009.

${ }^{4}$ Tetra Tech, Inc., 2004.

${ }^{5}$ The term "implicitly" is used when a flow element is not included explicitly in the model but is addressed in combination with other hydrologic elements or as a coefficient. 
Table 3. Characteristics and hydrologic elements of the surveyed groundwater models:

[Shaded columns indicate models currently in use. USGS, U.S. Geological Survey; NMOSE, New Mexico Office of the State Engineer; LANL, Los Alamos National Laboratory; SSPA, S.S. Papadopulos \& Associates Inc.; ISC, New Mexico Interstate Stream Commission; NA, not applicable; predevel, predevelopment; mi, miles; ft, feet; ET, evapotranspiration]

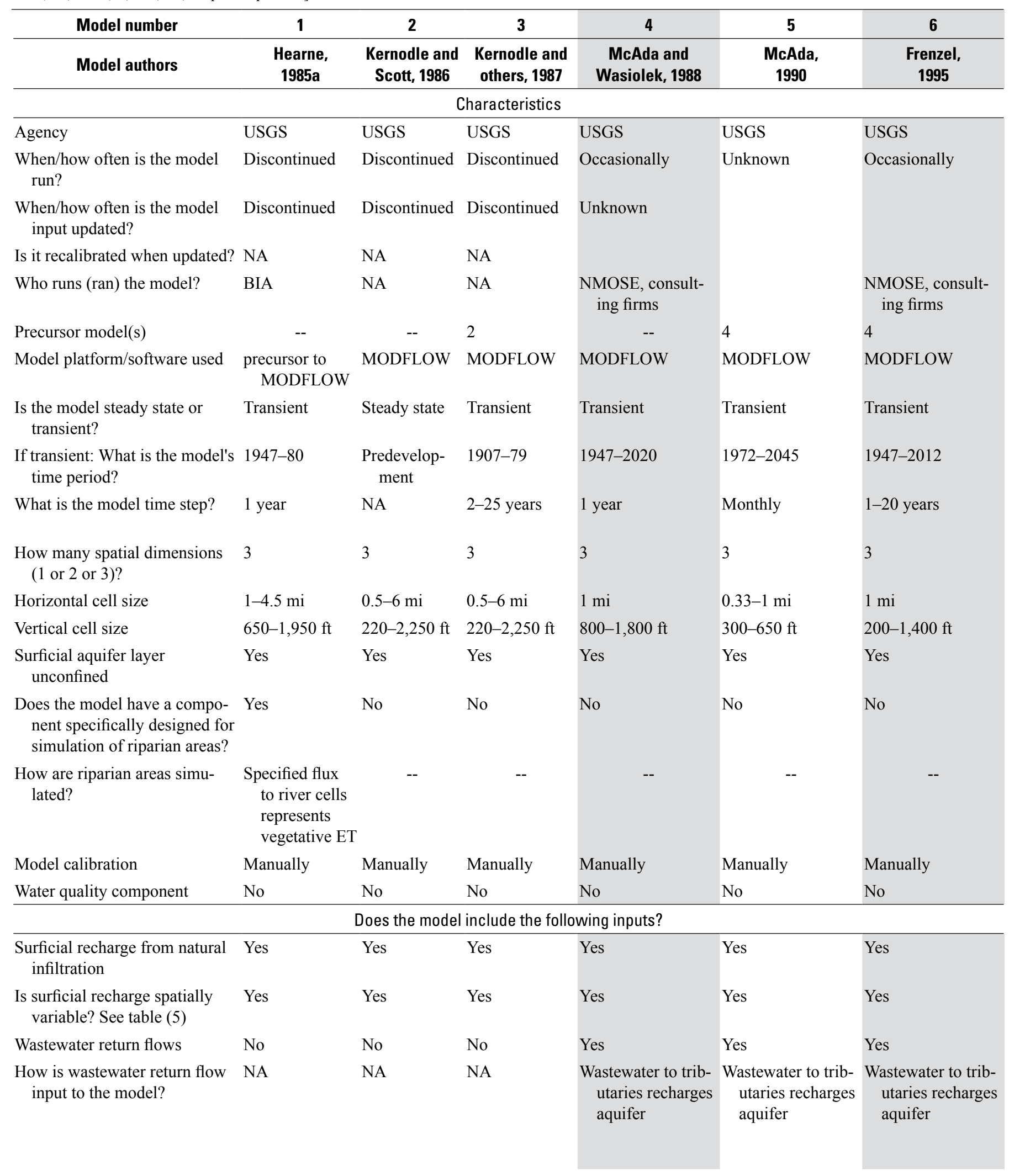




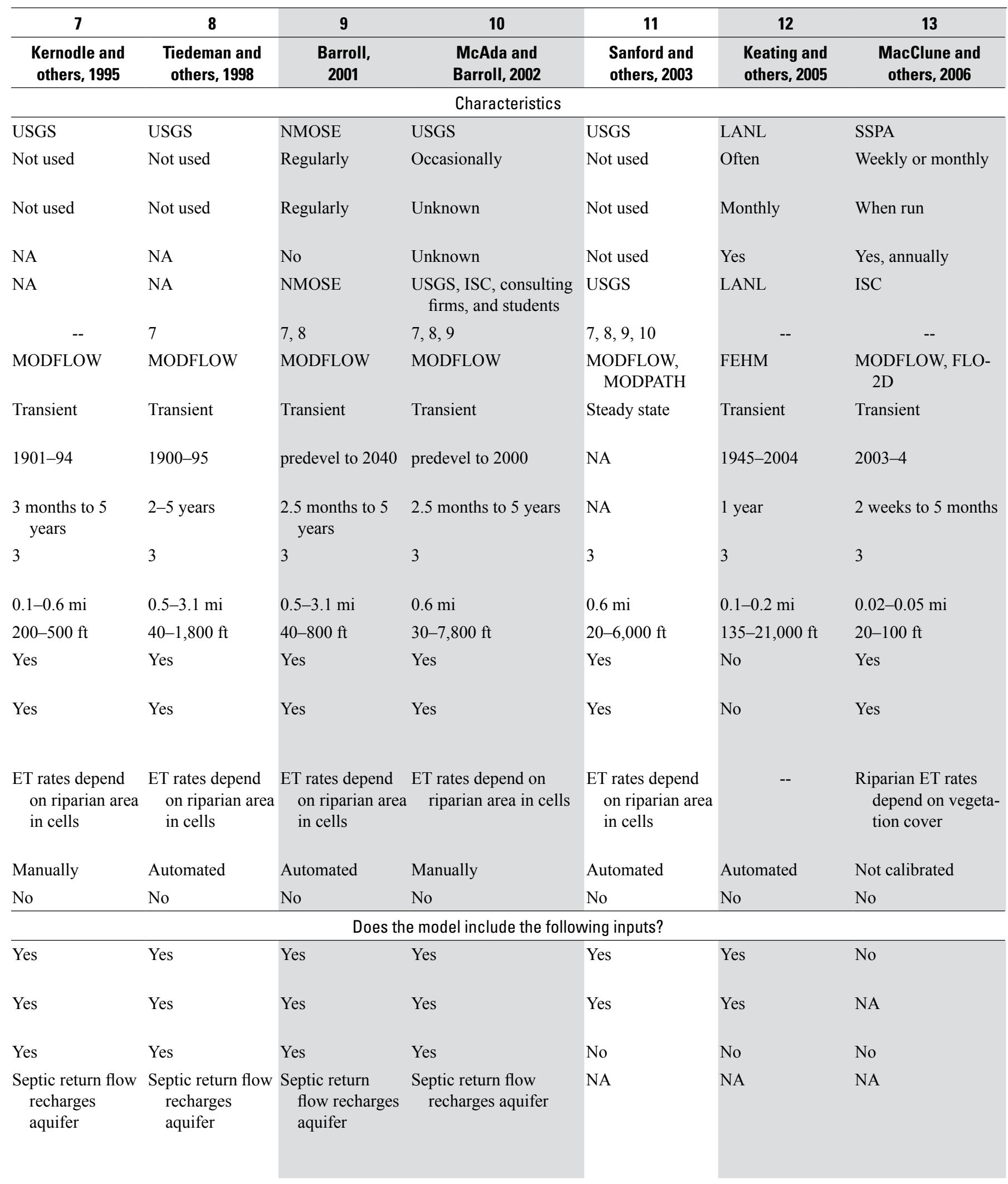


Table 3. Characteristics and hydrologic elements of the surveyed groundwater models. - Continued

[Shaded columns indicate models currently in use. USGS, U.S. Geological Survey; NMOSE, New Mexico Office of the State Engineer; LANL, Los Alamos National Laboratory; SSPA, S.S. Papadopulos \& Associates Inc.; ISC, New Mexico Interstate Stream Commission; NA, not applicable; predevel, predevelopment; mi, miles; ft, feet; ET, evapotranspiration]

\begin{tabular}{|c|c|c|c|c|c|c|}
\hline Model number & 1 & 2 & 3 & 4 & 5 & 6 \\
\hline Model authors & $\begin{array}{l}\text { Hearne, } \\
\text { 1985a }\end{array}$ & $\begin{array}{l}\text { Kernodle and } \\
\text { Scott, } 1986\end{array}$ & $\begin{array}{l}\text { Kernodle and } \\
\text { others, } 1987\end{array}$ & $\begin{array}{c}\text { McAda and } \\
\text { Wasiolek, } 1988\end{array}$ & $\begin{array}{c}\text { McAda, } \\
1990\end{array}$ & $\begin{array}{l}\text { Frenzel, } \\
1995\end{array}$ \\
\hline Domestic well withdrawals & No & No & No & Yes & No & No \\
\hline Groundwater injection & No & No & No & No & No & No \\
\hline \multicolumn{7}{|c|}{ Are the following processes explicitly modeled? } \\
\hline Irrigation return flows & No & No & No & No & No & No \\
\hline $\begin{array}{l}\text { How is irrigation return flow } \\
\text { modeled? }\end{array}$ & NA & NA & NA & NA & NA & NA \\
\hline Is ET time varying? & No & NA & NA & NA & NA & NA \\
\hline Springflow & No & No & No & No & No & No \\
\hline Groundwater withdrawals & Yes & No & Yes & Yes & Yes & Yes \\
\hline $\begin{array}{l}\text { Data source for groundwater } \\
\text { withdrawals }\end{array}$ & $\begin{array}{l}\text { Data from Pub- } \\
\text { lic Service } \\
\text { Co. Of NM }\end{array}$ & NA & NMOSE & $\begin{array}{l}\text { Data from NMOSE } \\
\text { and Sangre de } \\
\text { Cristo Water } \\
\text { Company }\end{array}$ & $\begin{array}{l}\text { Data from NMOSE } \\
\text { and Sangre de } \\
\text { Cristo Water } \\
\text { Company }\end{array}$ & $\begin{array}{l}\text { Data from NMOSE } \\
\text { and Sangre de } \\
\text { Cristo Water } \\
\text { Company }\end{array}$ \\
\hline
\end{tabular}

\begin{tabular}{|c|c|c|c|c|c|c|}
\hline \multicolumn{7}{|c|}{ Does the model include the following outputs explicitly? } \\
\hline Groundwater Levels & Yes & Yes & Yes & Yes & Yes & Yes \\
\hline Base flow/Streamflow & Yes & No & No & Yes & Yes & Yes \\
\hline $\begin{array}{l}\text { Recharge/seepage from surface } \\
\text { water to aquifer }\end{array}$ & Yes & Yes & Yes & Yes & Yes & Yes \\
\hline Springflow & No & No & No & No & No & No \\
\hline \multicolumn{7}{|c|}{ Were the following data used to calibrate or parameterize the model? } \\
\hline $\begin{array}{l}\text { Water level measurements in } \\
\text { wells }\end{array}$ & Yes & Yes & Yes & Yes & Yes & Yes \\
\hline Land use/vegetative cover data & Yes & No & No & No & No & No \\
\hline
\end{tabular}




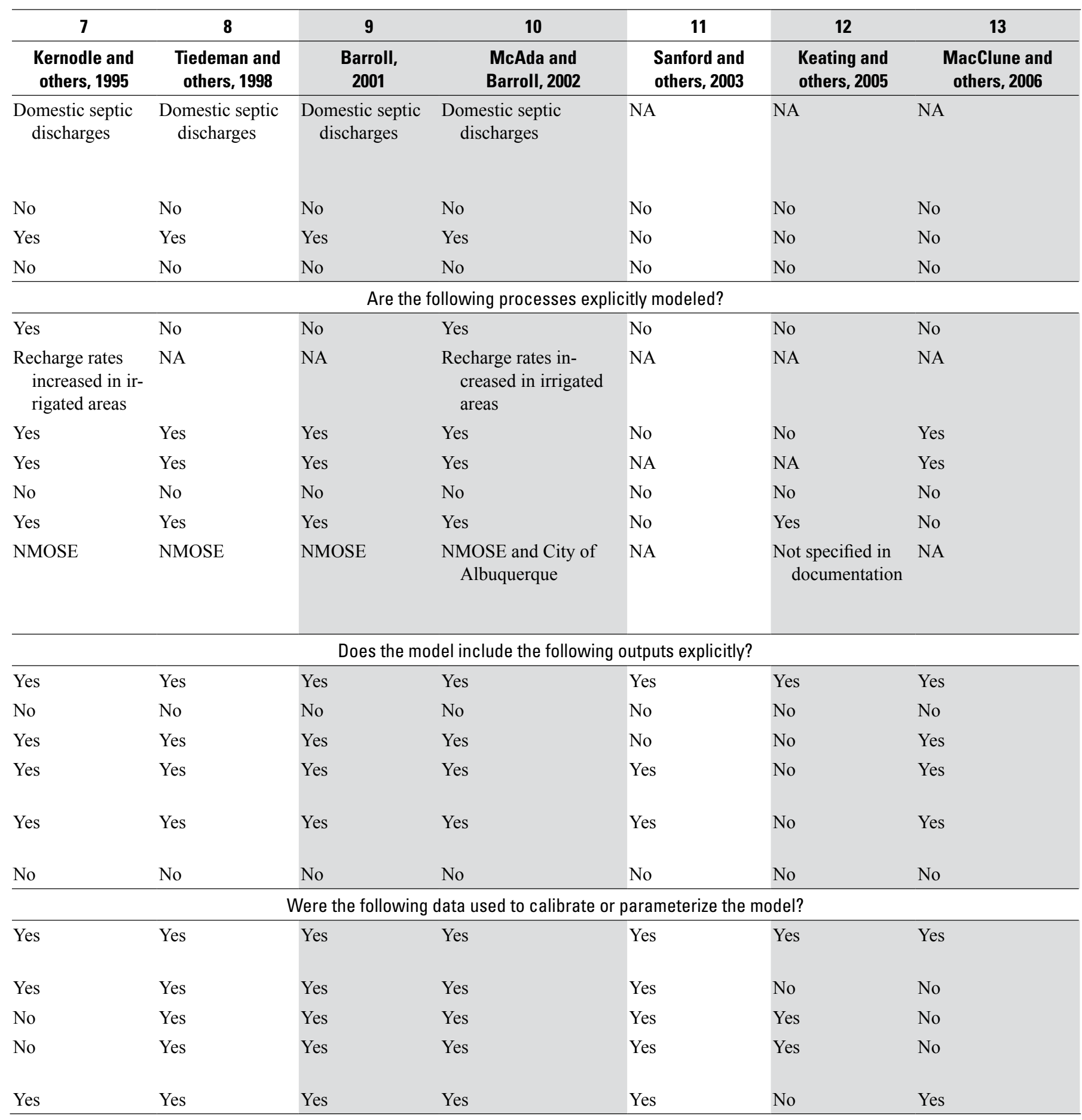


Table 4. Well fields included in each groundwater model.

[Shaded columns indicate models currently in use]

\begin{tabular}{|c|c|c|c|c|c|c|}
\hline Model number & 1 & 2 & 3 & 4 & 5 & 6 \\
\hline Model & $\begin{array}{c}\text { Hearne, } \\
\text { 1985a }\end{array}$ & $\begin{array}{l}\text { Kernodle and } \\
\text { Scott, } 1986\end{array}$ & $\begin{array}{c}\text { Kernodle and } \\
\text { others, } 1987\end{array}$ & $\begin{array}{c}\text { McAda and } \\
\text { Wasiolek, } 1988\end{array}$ & $\begin{array}{c}\text { McAda, } \\
1990\end{array}$ & $\begin{array}{c}\text { Frenzel, } \\
1995\end{array}$ \\
\hline \multicolumn{7}{|l|}{ Well field name } \\
\hline Guaje & Yes & No & No & Yes & No & Yes \\
\hline Panjarito & Yes & No & No & Yes & No & Yes \\
\hline Buckman & Yes & No & No & Yes & Yes & Yes \\
\hline Albuquerque & No & No & Yes & No & No & No \\
\hline
\end{tabular}




\begin{tabular}{|c|c|c|c|c|c|c|c|}
\hline Model number & 7 & 8 & 9 & 10 & 11 & 12 & 13 \\
\hline Model & $\begin{array}{l}\text { Kernodle and } \\
\text { others, } 1995\end{array}$ & $\begin{array}{l}\text { Tiedeman and } \\
\text { others, } 1998\end{array}$ & $\begin{array}{c}\text { Barroll, } \\
2001\end{array}$ & $\begin{array}{l}\text { McAda and } \\
\text { Barroll, } 2002\end{array}$ & $\begin{array}{l}\text { Sanford and } \\
\text { others, } 2003\end{array}$ & $\begin{array}{l}\text { Keating and } \\
\text { others, } 2005\end{array}$ & $\begin{array}{l}\text { MacClune and } \\
\text { others, } 2006\end{array}$ \\
\hline \multicolumn{8}{|l|}{ Well field name } \\
\hline Guaje & No & No & No & No & No & Yes & No \\
\hline Los Alamos & No & No & No & No & No & Yes & No \\
\hline Panjarito & No & No & No & No & No & Yes & No \\
\hline Buckman & No & No & No & No & No & Yes & No \\
\hline Albuquerque & Yes & Yes & Yes & Yes & No & No & No \\
\hline Otowi & No & No & No & No & No & Yes & No \\
\hline Santa Fe & No & No & No & No & No & No & No \\
\hline
\end{tabular}


Table 5. Factors used by each surveyed groundwater model to simulate recharge.

[Shaded columns indicate models currently in use]

\begin{tabular}{|c|c|c|c|c|c|c|}
\hline & $\begin{array}{c}\text { Hearne, } \\
\text { 1985a }\end{array}$ & $\begin{array}{l}\text { Kernodle and } \\
\text { Scott, } 1986\end{array}$ & $\begin{array}{c}\text { Kernodle and } \\
\text { others, } 1987\end{array}$ & $\begin{array}{c}\text { McAda and } \\
\text { Wasiolek, } 1988\end{array}$ & $\begin{array}{c}\text { McAda, } \\
1990\end{array}$ & $\begin{array}{c}\text { Frenzel, } \\
1995\end{array}$ \\
\hline & 1 & 2 & 3 & 4 & 5 & 6 \\
\hline \multicolumn{7}{|c|}{ Is recharge spatially variable? } \\
\hline & Yes & Yes & Yes & Yes & Yes & Yes \\
\hline Elevation dependent & No & No & No & Yes & Yes & Yes \\
\hline Surface geology dependent & No & No & No & Yes & Yes & Yes \\
\hline Mountain-front seepage & Yes & Yes & Yes & Yes & Yes & Yes \\
\hline
\end{tabular}




\begin{tabular}{|c|c|c|c|c|c|c|c|}
\hline & $\begin{array}{c}\text { Kernodle and } \\
\text { others, } 1995\end{array}$ & $\begin{array}{c}\text { Tiedeman and } \\
\text { others, } 1998\end{array}$ & $\begin{array}{c}\text { Barroll, } \\
2001\end{array}$ & $\begin{array}{l}\text { McAda and } \\
\text { Barroll, } 2002\end{array}$ & $\begin{array}{l}\text { Sanford and } \\
\text { others, } 2003\end{array}$ & $\begin{array}{l}\text { Keating and } \\
\text { others, } 2005\end{array}$ & $\begin{array}{l}\text { MacClune and } \\
\text { others, } 2006\end{array}$ \\
\hline & 7 & 8 & 9 & 10 & 11 & 12 & 13 \\
\hline \multicolumn{8}{|c|}{ Is recharge spatially variable? } \\
\hline & Yes & Yes & Yes & Yes & Yes & Yes & No \\
\hline Elevation dependent & No & No & No & No & No & Yes & No \\
\hline Surface geology dependent & No & Yes & Yes & No & No & No & No \\
\hline Mountain-front seepage & Yes & Yes & Yes & Yes & Yes & No & No \\
\hline
\end{tabular}


Table 6. Methods used for modeling surface-water/groundwater interactions in the groundwater models surveyed.

[Shaded columns indicate models currently in use]

\begin{tabular}{ccccccc}
\hline Model & 1 & 2 & 3 & 4 & 5 & 6 \\
\hline & $\begin{array}{c}\text { Hearne, } \\
1985 a\end{array}$ & $\begin{array}{c}\text { Kernodle and } \\
\text { Scott, 1986 }\end{array}$ & $\begin{array}{c}\text { Kernodle and } \\
\text { others, 1987 }\end{array}$ & $\begin{array}{c}\text { McAda and } \\
\text { Wasiolek, 1988 }\end{array}$ & $\begin{array}{c}\text { McAda, } \\
1990\end{array}$ & $\begin{array}{c}\text { Frenzel, } \\
1995\end{array}$ \\
\hline
\end{tabular}

Methods used to model surface-water recharge to groundwater

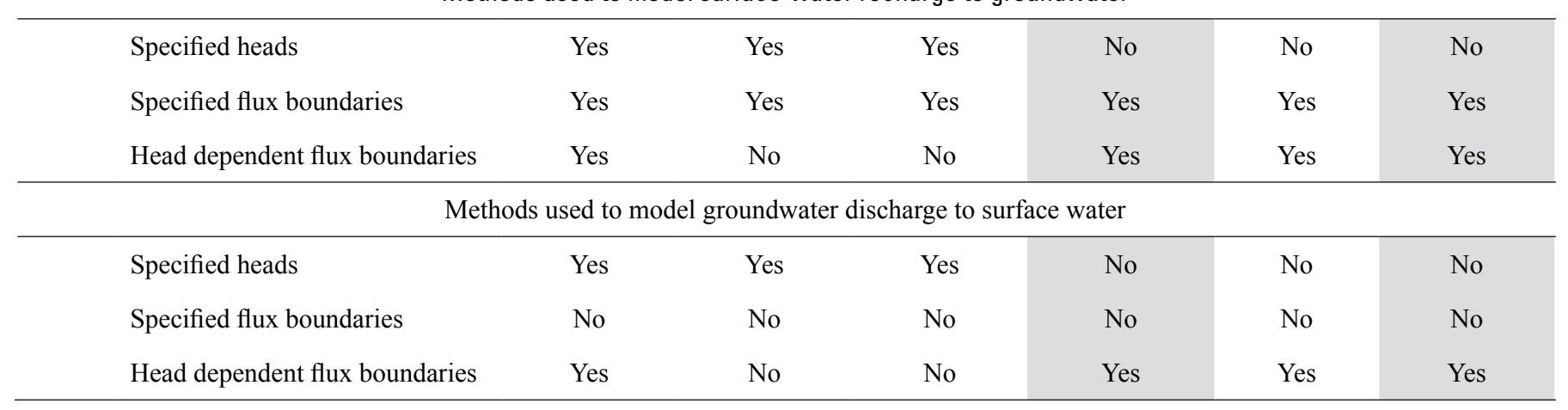




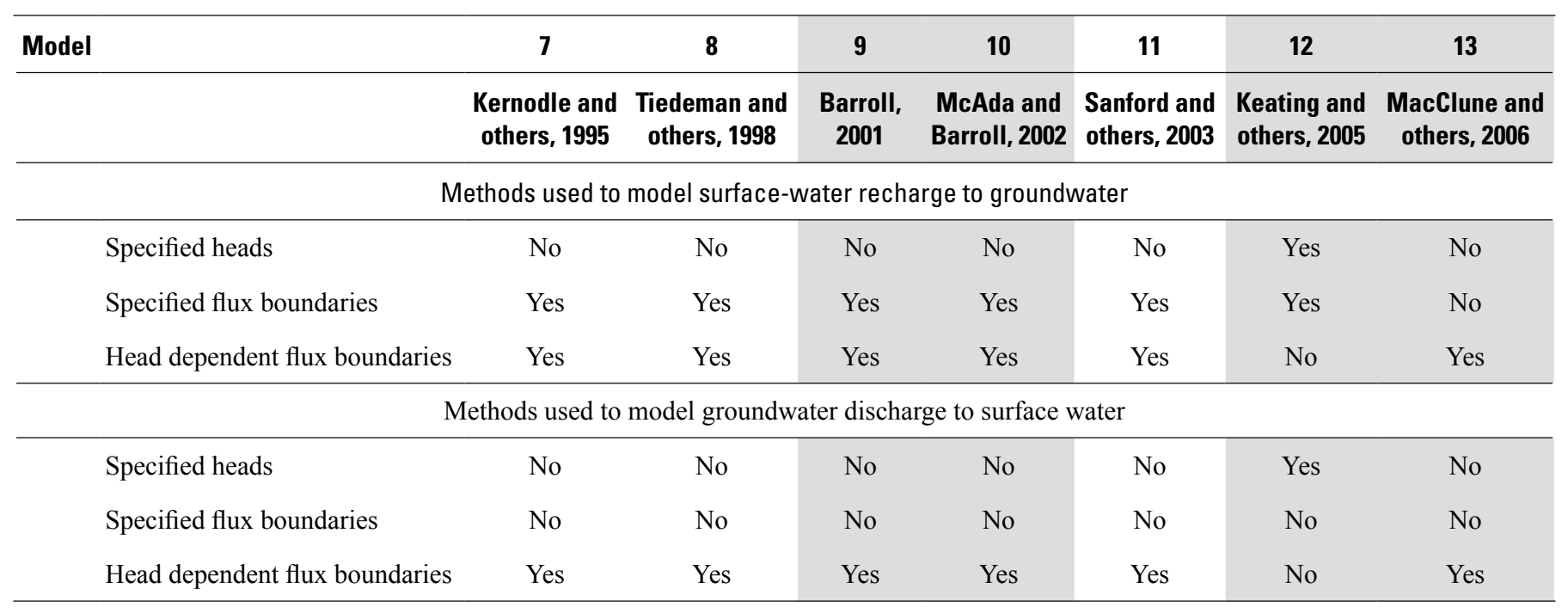




